\section{Research Square}

\title{
Horizontal tectonics assembled unrelated crustal blocks in the Paleoarchean
}

\section{Mudlappa Jayananda ( $\sim$ mjayan.geol@gmail.com )}

University of Hyderabad https://orcid.org/0000-0002-2518-231X

\section{Martin GUITREAU}

Université Clermont Auvergne https://orcid.org/0000-0001-7156-6536

\section{Aadhiseshan Krishnaswami Ravindran}

University of Hyderabad

\section{Sun-Lin Chung}

National Taiwan University https://orcid.org/0000-0002-5362-4496

\section{Takashi Miyazaki}

Japan Agency for Marine-Earth Science \& Technology (JAMSTEC) https://orcid.org/0000-0002-08893961

\section{Article}

Keywords: horizontal tectonics, crustal blocks, Paleoarchean

Posted Date: December 11th, 2020

DOl: https://doi.org/10.21203/rs.3.rs-122833/v1

License: (c) (i) This work is licensed under a Creative Commons Attribution 4.0 International License.

Read Full License 


\section{Horizontal tectonics assembled unrelated crustal blocks in the Paleoarchean}

M. Jayananda ${ }^{1 *}$, Martin Guitreau ${ }^{2}$, K.R. Aadhiseshan ${ }^{1}$, S.L. Chung ${ }^{3}$., T. Miyazaki ${ }^{4}$

1. Centre for Earth, Ocean \& Atmospheric Sciences, University of Hyderabad, Gachibowli, Hyderabad -500 046, India

2. Université Clermont Auvergne, IRD, CNRS, OPGC, Laboratoire Magmas et Volcans, UMR 6524, F-63000 Clermont-Ferrand, France

3. Institute of Earth Sciences, Academia Sinica, Nangang, Taipei 11529, Taiwan

4. Research Institute for Marine Geodynamics (IMG), Japan Agency for Marine-Earth Science \& Technology (JAMSTEC), Yokosuka, Kanagawa 237-0061, Japan

* corresponding author

\section{Abstract}

Archean geodynamics and craton formation are topics of much debate for decades. Here we present new evidence from field, petrography, geochronology, elements and Nd-Hf isotope geochemistry for origin of Paleoarchean micro-blocks in different geodynamic environments and their assembly into cratonic framework through horizontal motion. The cratonal core in the western Dharwar craton, southern India formed through assembly of three genetically unrelated micro-blocks: a microcontinent with oceanic plateau remnants, an oceanic arc, and a section of oceanic lithosphere. Isotopic age data from these micro-blocks and surrounding basement gneisses indicate that the assembly of micro-blocks marked by intrusions of hot trondhjemite magmas that drive partial convective crustal overturn, thus resulting in dome-and-keel structures visible in the Archean cratons. Our study reveals horizontal motion of unrelated tectonic units during the Paleoarchean, while mantle plumes driven vertical accretion contributed to major crustal growth allowing geodynamic linkage between Paleoarchean cratons. 


\section{Debate on Archean tectonics}

Tectonics of the evolving early Earth, origin of protocontinents and craton formation are topics of much debate in Earth and Planetary Sciences. Present day dynamics of the planet Earth is driven by plate tectonics but when this regime initiated and what kind of processes were in operation during Archean has remained highly controversial for decades ${ }^{1-2}$. Several hypotheses have been put forth such as heat-pipe ${ }^{3}$, stagnant $\operatorname{lid}^{4}$, plate tectonics ${ }^{5}$, mixed models ${ }^{6}$, and some authors emphasize the evolution of processes and/or the transition between specific regimes ${ }^{7-8}$. Major arguments for Archean geodynamics are based on lithological assemblages $^{9-10}$, tectonic fabrics ${ }^{11-12}$, geochemistry ${ }^{13-14}$, geophysics ${ }^{15}$, and numerical modeling ${ }^{16-17}$. Subduction is often argued as major process to explain geochemistry and origin of TTGs and mafic rocks (e.g., ${ }^{18-19 ; 2}$ ) but non-uniformitarian models involving melting of stagnant lid by plumes have also been proposed ${ }^{20-21}$. A central aspect of this uncertainty relies on how one interprets Archean greenstone belts. Do they represent oceanic crust $^{3,10}$, oceanic plateaus $^{22}$, or back-arc basins ${ }^{23}$ and what is their relationship with adjoining granitoids?

Archean cratons differ from their present-day counterparts by exhibiting strong dichotomous lithologies made of greenstone belts (ultramafic to mafic lavas, detrital and chemical sediments) and granitoids (TTG; tonalite-trondhjemite-granodiorite, e.g., ${ }^{24}$ ). The geodynamic context of formation and processes responsible for their association are still disputed (e.g., ${ }^{4,21,25-26}$ ). Addressing these issues is crucial as they bear a great deal on the thermal and chemical evolution of the early Earth, formation of habitable continents and emergence of biosphere. Here we address the geodynamic context of Archean crustal growth and craton formation from our target study in the Western Dharwar Craton (WDC), Southern India (Fig.1). We assess evidence for role of vertical accretion in building of early protocrust 
as well as role of horizontal motion in assembly unrelated micro-blocks leading to craton formation. Addressing this question is key to unravel the geodynamics of Archean Earth and this is the purpose of the present contribution.

\section{Western Dharwar craton (WDC) - An ideal target}

The WDC is an ideal target to address Archean geodynamics because it forms a wide time (3600-3200 Ma) and tectonic window with typical dome-keel architecture from mid-to lower crustal levels due to northward tilting ${ }^{27-29}$. The cratonal core in the vicinity of Holenarsipur greenstone belt ${ }^{30}$ preserves ca. 3430-3270 Ma granitoids of tonalite-trondhjemitegranodiorite (TTGs) - greenstone assemblages which in turn intruded by ca. 3200 diapiric trondhjemites ${ }^{31-32}$ coinciding with development of regional dome and keel patterns ${ }^{33}$. Yet, older crust played a role in the formation of the WDC as evidenced by $>3450$ Ma detrital and inherited zircon crystals $\left({ }^{34,32, \text { this study }}\right)$ as well as by $\mathrm{Hf}, \mathrm{Nd}$ and $\mathrm{Pb}$ isotope signatures ${ }^{35,31-32}$. However, mechanisms and tectonic context of crust accretion are debated as the greenstone sequences and adjoining granitoid basement have been interpreted as oceanic plateau and island $\operatorname{arc}^{31,36-37}$ flat subduction of plume fed oceanic plateau crust ${ }^{38}$, remnants of migrating oceanic crust from spreading centre to trench ${ }^{39}$. Holenarsipur greenstone belt is considered to be a collage of two distinct stratigraphic units ${ }^{40}$, for which various types of data presented including geological ${ }^{41}$ strain fabrics ${ }^{33}$, elemental and isotope data $(31-32,37-38,42-43)$. Here we present a multidisciplinary study on the Holenarsipur greenstone belt and adjoining TTGs that allows identification of distinct tectonic blocks and their assembly through horizontal motion which further discussed on global scale in the light of data from other cratons.

\section{Three tectonic blocks}

Field, elemental, Nd-Hf isotope data revealed three tectonic units that we labelled Southwestern, Northcentral, and Eastern blocks (Fig.1). 

with minor mafic rocks associated with sediments and adjoining TTGs. Abundance of ultramafic-mafic rocks gradually increases from large discontinuous outcrops within the granitoids to continuous outcrops from south to north of the southwestern block. The ultramafic rocks occasionally forming pillows with chilled margins indicating eruption in marine environment. The adjoining ca.3430-3300 Ma TTGs are intruded by ca. 3200 Ma diapiric trondhjemites.

The Northcentral block comprises dominant greenstone assemblages including ultramafic to mafic volcanics with minor felsic pyroclastic flows and interlayered pelites. The greenstone unit fragmented by the intrusion of ca. 3200 Ma diapiric trondhjemites (see fig.1). Ultramafic-mafic rocks erupted in marine environment as revealed by crude pillows and flow top pillow breccias. Felsic volcanics are confined to higher stratigraphic levels erupted in subaerial environment. Chlorite-chloritoid-garnet bearing pelitic sediments along southern boundary imply ultramafic to mafic provenance and deposited in oceanic environment far from sizable continent. These characteristics of the greenstone assemblages points to oceanic arc setting. The greenstone volcanics show the imprints of contact metamorphism along their contact zone with ca. 3200 Ma diapiric trondhjemite as evidenced by large randomly oriented actinolite, tremolite and hornblende crystals. Numerous quartz-veins with large tourmaline crystals inject into the greenstone volcanics along the contact zone with diapiric trondhjemite. The Eastern block is a thin (500 $\mathrm{m}$ to $3 \mathrm{~km}$ width) elongated volcanic-sedimentary assemblage that runs for about $60 \mathrm{~km}$ in north-south direction (Line B of Fig.1). In its northern part, an E-W road cut displays a complete section of volcano-sedimentary sequence. From east to west, the sequence begins with pillowed mafic-ultramafic rocks with chilled margins followed by phyllite clays, chert layers, BIFs, several fine grained sheeted mafic dykes, plagiogranite, gabbros to layered gabbros, fine grained ultramafic rocks to medium grained 
peridotitic komatiites to the westernmost part (Fig. 2a, b). Further west, peridotitic komatiites show tectonic contacts with surrounding TTGs. The southern part of it corresponds to deeper level that displays talc-tremolite, actinolite-hornblende schist, gabbro-anorthosite and plagiogranite and peridotitic komatiites along east - west section. These two E-W crosssections could correspond to a titled panel of preserved oceanic crust close to a spreading centre (Fig. 2c).

The contact relationships between the three tectonic units are key in understanding crustal architecture and assembly of these distinct blocks into cratonal framework. Sedimentary assemblages found along the margins of each block imply distinct tectonic settings. Along the northern limit of Southwestern block a thick quartzite with crossbedding and ripple marks is followed by quartz-pebble conglomerate which mark shallow shelf conditions with a dominant granitic source. These quartzite-conglomerate layers are followed by quartz-mica-kyanitestaurolite-garnet bearing pelite associated with ultramafic rocks and TTGs that indicate mixed provenance forming a possible continental nucleus with oceanic plateau fragments. The chlorite-chloritoid-garnet bearing pelite of the Northcentral block found along its southern margin consistent with oceanic setting. Within the Eastern block, close to the contact with the Northcentral block, a polymict conglomerate without any clast supported framework ${ }^{40}$ containing sparse angular fragments of greenstone volcanics/sediments with fine grained matrix indicate local fragmentation within the basin. An interpretative south-west to north-east cross-section covering three blocks (Line A of Fig. 1) display fundamental architecture of the cratonal core showcasing vertical motions driven by body forces followed by crustal shortening (Fig. 3).

\section{Timing of greenstone volcanism and adjoining basement granitoids}



are tectonized. It is difficult to provide precise ages for ultramafic volcanism as ${ }^{147} \mathrm{Sm} /{ }^{144} \mathrm{Nd}$ ratios of samples were affected to some extent by fluid flow associated with metamorphism and emplacement of ca. 3200 Ma diapiric trondhjemites. Ultramafic to mafic rocks of all the three blocks together define $\mathrm{Sm}-\mathrm{Nd}$ whole rock isochron age of $3028 \pm 53.3 \mathrm{Ma}(\mathrm{MSWD}=2.3$, figure not given) which represents cooling path of amphibolite facies event dated at $3091 \pm 12$ $\mathrm{Ma}^{31}$. The ultramafic-mafic volcanics of Southwestern block define Sm-Nd whole rock isochron age of $3029 \pm 91.5 \mathrm{Ma}$ (MSWD 1.2, figure is not given) which coincides with metamorphic cooling. The occurrence of ultramafic-mafic volcanics as large disrupted

$\mathrm{U}-\mathrm{Pb}$ zircon ages of this study together with published zircon ages $\mathrm{s}^{31-32,43}$ of adjoining levels define $3305 \pm 10 \mathrm{Ma}$ (see fig. $6 \mathrm{c}$ in supplementary file). TTGs adjoining to the 
and adjoining TTGs remain uncertain due to tectonized contacts but $3305 \pm 10$ Ma pyroclastic flows may represent a terminal stage of greenstone volcanism.

The greenstone volcanics of the Eastern block provide Sm-Nd whole rock isochron age of $3345 \pm 111 \mathrm{Ma}$ (MSWD=1.8; figure is not given) which is close to U-Pb zircon of $3347 \pm 11$ Ma of plagiogranite (fig.7 in supplementary file) interlayered with gabbroic rocks in the northern roadcut which probably marks terminal stage of volcanism. Published U-Pb zircon ages of basement TTGs from the western margin of the Eastern block indicate younger ages of $3276 \pm 5 \mathrm{Ma}^{31}$ and $3289 \pm 5 \mathrm{Ma}^{43}$.

\section{Geochemical fingerprinting of three tectonic blocks}

The petrogenetic interpretations were made on samples devoid of evident alteration and weathering. However, exact petrological type of ultramafic-mafic rocks from three blocks may not be good indicators of their origin, but geochemical signatures can help constrain source reservoirs and unravel the geodynamic context of formation of such rocks (e.g., $\left.{ }^{18,44}\right)$.

Major elements of volcanics from three greenstone units plotted on triangular diagrams $\left(\mathrm{Al}_{2} \mathrm{O}_{3}-\mathrm{Fe}_{2} \mathrm{O}_{3}+\mathrm{TiO}_{2}-\mathrm{MgO}\right.$ Fig. $\left.4 \mathbf{a} ;{ }^{73}\right)$ and $\left(\mathrm{CaO}-\mathrm{MgO}-\mathrm{Al}_{2} \mathrm{O}_{3}\right.$ Fig.4b $\left.{ }^{74}\right)$ reveal dominant komatiite to komatiite basalt composition whilst exhibit distinct trace element signatures marking independent histories.

\section{Southwestern block - Oceanic plateau with remnants of microcontinent}

Incompatible elements content (REE, Nb, Y, Th, Zr; Fig. 8a-d and data table in supplementary file) reveal two groups. The low REE group ( $\Sigma$ REE $=4.77-19.17$ ppm with lower $\mathrm{SiO}_{2}$ 44.09-45.97 wt\%) exhibit flat to slightly fractionated REE patterns (Fig. 8a in supplementary file) with $(\mathrm{Gd} / \mathrm{Yb})_{\mathrm{N}} 0.53-1.86$ indicating their derivation by high degree melting of shallow depleted mantle without significant residual garnet. This is consistent with absence of $\mathrm{Nb}$ anomalies together with positive $\mathrm{Zr}$ and $\mathrm{Y}$ anomalies on primitive mantle ${ }^{71}$ normalized 
spider diagram (Fig.8b in supplementary file). The high REE group $(\Sigma \mathrm{REE}=20.6-66.6 \mathrm{ppm})$ with fractionated REE $\left[(\mathrm{Gd} / \mathrm{Yb})_{\mathrm{N}}\right.$ 1.22-2.29, Fig.8c in supplementary file] together with positive $\mathrm{Nb}$, coupled negative $\mathrm{Zr}$ and $\mathrm{Hf}$ anomalies on spider diagrams (Fig.8d in supplementary file) suggest origin of melts from deeper primitive mantle with possible residual majorite?.

Initial ${ }^{143} \mathrm{Nd} /{ }^{144} \mathrm{Nd}$ ratios of komatiites were used to calculate $\varepsilon_{\varepsilon} \mathrm{Nd}_{(\mathrm{T}=3400 \mathrm{Ma})}$ values to constrain mantle sources and possible crustal contamination. Nine samples with large range of values $\left({ }_{\varepsilon} \mathrm{Nd}_{(\mathrm{T})}=0.4\right.$ to 3.7$)$ suggest chondritic to depleted mantle reservoirs whilst two samples with negative $\left({ }_{\varepsilon} \mathrm{Nd}_{(\mathrm{T})}=-3.0\right.$ to -0.7$)$ values $($ Fig.5) related to possible contamination of preexisting crust ${ }^{32,35}$. Plots of incompatible element ratios like $\mathrm{Th} / \mathrm{Yb}$ versus $\mathrm{Nb} / \mathrm{Yb}$ (Fig. 6a. after $^{72}$ ) and $\mathrm{Nb} / \mathrm{Y}$ versus $\mathrm{Zr} / \mathrm{Y}$ (Fig.6b after $^{44}$ ) suggest primitive to depleted mantle whilst $\mathrm{Zr} / \mathrm{Nb}$ versus $\mathrm{Nb} / \mathrm{Th}_{\text {plot }}{ }^{44}$ attribute their eruption as oceanic plateaus (Fig.6c).

Nortcentral block - Oceanic arc with coeval mini volcanic plateau fragments?

Major element data $\left(\mathrm{SiO}_{2}=45.11\right.$ to $68.65 \mathrm{wt} \% ; \mathrm{MgO}=23.92$ to $\left.1.29 \mathrm{wt} \%\right)$ reveal komatiite, komatiite basalt, basalt to dacite in composition. Komatiites contain low to moderate ¿REE (14.6-59.1 ppm), display flat REE patterns with $(\mathrm{Gd} / \mathrm{Yb})_{\mathrm{N}}$ ratios of $0.99-1.68$ (Fig.9a in supplementary file) whilst komatiite basalts show moderate to high $\Sigma$ REE (27.3-138.0 ppm) displaying flat to fractionated REE patterns $\left.\left[(\mathrm{Gd} / \mathrm{Yb})_{\mathrm{N}}=0.94-1.93\right)\right]$ (Fig. $9 \mathrm{~b}$ in supplementary file) implying heterogeneous mantle reservoirs whilst negative $\mathrm{Nb}$ anomalies coupled with either positive or no significant $\mathrm{Zr}$, Hf and $\mathrm{Y}$ anomalies on spider diagrams (Fig.9c,d in supplementary file) suggest origin from shallower mantle. These elemental characteristics, lithological association of komatiite-komatiite basalt- basalt- dacite points to oceanic arc signatures. Incompatible element ratios like $\mathrm{Th} / \mathrm{Yb}$ versus $\mathrm{Nb} / \mathrm{Yb}$ (see fig. 6a) and $\mathrm{Nb} / \mathrm{Y}$ versus $\mathrm{Zr} / \mathrm{Y}$ (see fig. 6b) indicate heterogenous reservoirs involving primitive to depleted mantle with 
a half number of samples show modern $\mathrm{N}-\mathrm{MORB}$ signatures whilst on $\mathrm{Zr} / \mathrm{Nb}$ versus $\mathrm{Nb} / \mathrm{Th}$ studied samples extending arc to oceanic plateau setting wherein komatiite may represent volcanic plateau fragment adjacent to oceanic arc (see fig. 6c). Initial Nd isotope ratios of ten samples $\left(\varepsilon \mathrm{Nd}_{(\mathrm{T})}=3300 \mathrm{Ma}\right.$ ) showing 1.4 to 5.8 (three samples with ${ }_{\varepsilon} \mathrm{Nd}_{(\mathrm{T})}=-5.6$ to -0.9$)$ suggest chondritic to depleted mantle source with traces of ancient crustal contamination (see fig. 5).

The komatiitic to basaltic volcanics with $\mathrm{SiO}_{2}$ ranging 42.74-50.03 wt\% form two groups: low $\Sigma$ REE and high $\Sigma$ REE. Initial $\mathrm{Nd}$ isotope ratios of twelve samples $(\varepsilon \mathrm{Nd}(\mathrm{T})=3350$ Ma) showing -0.8 to 5.5 (except for three samples with anomalous values ${ }_{\varepsilon} \mathrm{Nd}_{(\mathrm{T})}=-18.3$, -5.1 and -2.3). The low $\Sigma$ REE (5.80-22.20 ppm) group displays flat patterns with depletion in LREE, poorly fractionated $\left[(\mathrm{Gd} / \mathrm{Yb})_{\mathrm{N}}=0.61-1.38\right.$; Fig.10a in supplementary file $]$ which suggests depleted mantle similar to N-MORB. Absence of $\mathrm{Nb}$ anomalies coupled with positive $\mathrm{Zr}$, Y anomalies on spider diagram points to melts origin from shallow depleted mantle which is consistent with $\varepsilon \mathrm{Nd}_{(\mathrm{T}=3350 \mathrm{Ma})}$ ranging from 2.5 to 5.5 (Fig. 10b in supplementary file). On the contrary, the high $\Sigma$ REE (48.39-294.79 ppm) group shows fractionated REE (Fig.10c in supplementary file) patterns $\left[(\mathrm{Gd} / \mathrm{Yb})_{\mathrm{N}}=1.16-1.96\right]$ coupled with positive $\mathrm{Nb}$ anomalies and negative Hf-Y anomalies on spider diagrams (Fig. 10d in supplementary file) which coupled with $\varepsilon \mathrm{Nd}_{(\mathrm{T}=3350 \mathrm{Ma})}$ values (1.4 to -0.8$)$ suggest deeper primitive mantle. Element ratios like $\mathrm{Th} / \mathrm{Yb}$ versus $\mathrm{Nb} / \mathrm{Yb}$ and $\mathrm{Nb} / \mathrm{Y}$ versus $\mathrm{Zr} / \mathrm{Y}$ indicate their origin from $\mathrm{N}-\mathrm{MORB}$ to E-MORB sources (see figs.6a, b). Further, on $\mathrm{Zr} / \mathrm{Nb}$ versus $\mathrm{Nb} / \mathrm{Th}$ plot suggests shallow depleted to deep primitive mantle with affinities to modern N-MORB to E-MORB implying oceanic spreading setting (see fig. 6c). 

oceanic arc crust ${ }^{47}$, subducting oceanic plateau ${ }^{48}$ and stagnant lid/oceanic plateau in mantle upwelling zone $e^{4}$ proposed for origin of Archean TTGs. The lower $\mathrm{K}_{2} \mathrm{O} / \mathrm{Na}_{2} \mathrm{O}$ even at high $\mathrm{SiO}_{2}$ levels (>75 wt\%), HREE depletion and quartz-normative nature ${ }^{49-51}$ of TTGs preclude their origin by direct melting of mantle peridotite rather suggest mafic source.

Elemental and isotope characteristics of TTGs reveal two major groups: Older (3468$3400 \mathrm{Ma})$ dominantly low- $\mathrm{Al}_{2} \mathrm{O}_{3}(<14 \mathrm{wt} \%)$ with trondhjemite to granite composition whilst few samples with high- $\mathrm{Al}_{2} \mathrm{O}_{3}(>14 \mathrm{wt} \%)$. The younger (3350-3300 Ma) gneisses with low $\mathrm{Al}_{2} \mathrm{O}_{3}(<13.5 \mathrm{wt} \%)$ to high- $\mathrm{Al}_{2} \mathrm{O}_{3}(>15 \%)$ show tonalite to granodiorite composition. The older gneisses show higher $\mathrm{MgO}$ (up to 1.73 wt\%), $\mathrm{Fe}_{2} \mathrm{O}_{3}$ (upto 3.12 wt\%) despite high $\mathrm{SiO}_{2}(74-$ 76\%) together with variable total REE (36-336 ppm) and poorly fractionated REE (Fig. 13a in supplementary file) patterns $\left[(\mathrm{La} / \mathrm{Yb})_{\mathrm{N}}=0.35-2.3\right]$, less pronounced negative $\mathrm{Nb}-\mathrm{Ta}$ with positive $\mathrm{Y}$ anomalies (Fig. 13b in supplementary file) on spider diagrams argue for lowpressure melting of basaltic source without residual garnet. This is consistent with their subchondritic $\mathrm{Nb} / \mathrm{Ta}$ ratios together with low $\mathrm{Zr} / \mathrm{Sm}, \mathrm{Sr} / \mathrm{Y}, \mathrm{Gd} / \mathrm{Yb}$ and low $\mathrm{K}_{2} \mathrm{O} /\left(\mathrm{Na}_{2} \mathrm{O}+\mathrm{CaO}\right.$; Fig. 7a,b,c) suggesting low-pressure ( $\leq 10 \mathrm{kbar})$ melting. The two high- $\mathrm{Al}_{2} \mathrm{O}_{3}(>14 \mathrm{wt} \%)$ samples with higher $\mathrm{Ba}$, Sr, REE (232-282 ppm and moderately fractionated REE (see fig. 13a in supplementary file) patterns $[(\mathrm{La} / \mathrm{Yb})=12.6-27.6]$ with negative $\mathrm{Nb}-\mathrm{Ta}-\mathrm{Ti}$ anomalies (see fig. $13 \mathrm{~b}$ in supplementary file) originated by moderate pressure (12-14 kbar) melting of basaltic source with hornblende, plagioclase and traces of garnet in residue.

Melting of mafic source like modern-MORB with strong depletion in incompatible elements $\left[\left(0.16 \mathrm{wt} \% \mathrm{~K}_{2} \mathrm{O},<2.88 \mathrm{ppm} \mathrm{Rb}\right.\right.$ and $<29.2 \mathrm{ppm}$ of $\mathrm{Ba},(\mathrm{La} / \mathrm{Yb})_{\mathrm{N}}=<0.84 ; \mathrm{Sr} / \mathrm{Y}=<$ 
modelling ${ }^{54}$ together with high content of incompatible elements and $\mathrm{Nd}-\mathrm{Hf}$ isotope data preclude sources similar to MORB or komatiite but invoke chondritic to enriched mafic source $^{55-56}$. Majority of petrologic and geochemical data together numerical models argue against horizontal motion of plates prior to $3300 \mathrm{Ma}\left(\mathrm{e} \cdot \mathrm{g}^{4,57-58}\right)$. Therefore, melting of subducting oceanic crust can be ruled out for origin of $>3400$ Ma TTGs. Alternatively, melting of thick undepleted basaltic ${ }^{56}$ stagnant lid forming the base of oceanic plateau may be considered. Low pressure (10-12 kbar) melting under high thermal gradient $\left(>700^{\circ} \mathrm{C} / \mathrm{Gpa},{ }^{56}\right)$, in the mantle upwelling zone ${ }^{4}$ can generate TTGs melts with low $\mathrm{Sr} / \mathrm{Y}, \mathrm{Zr} / \mathrm{Sm}$ and $\mathrm{Gd} / \mathrm{Yb}$ ratios.

Our in-situ Hf isotope data of zircons together with published ${ }^{32}$ data $\left[\varepsilon \mathrm{Ef}_{(\mathrm{T})}=-2.4\right.$ to +2.3] of 3468-3400 Ma indicate short crustal history of their precursors and involvement of ancient $(>3600 \mathrm{Ma})$ crust $\left(\right.$ Fig. 8). This agrees with whole rock $\mathrm{Nd}$ isotope data $\left(\varepsilon N \mathrm{Nd}_{(\mathrm{T})}=0.8\right.$ to -2.8 ) of oldest gneisses ${ }^{31}$ and radiogenic $\mathrm{Pb}$ in feldspars of ca. $3400 \mathrm{Ma}$ gneisses indicating involvement of crustal protoliths as old as ca. $3800 \mathrm{Ma}^{35}$.

Among 3350-3300 Ma gneisses, the low- $\mathrm{Al}_{2} \mathrm{O}_{3}$ gneisses with higher $\mathrm{SiO}_{2}(72-79 \mathrm{wt} \%$ ), high total REE (299-1211ppm), moderately fractionated REE patterns, (Fig.13c in supplementary file) but less pronounced negative $\mathrm{Nb}$-Ta-Ti but strong negative $\mathrm{Sr}$ anomalies (Fig.13d in supplementary file) on spider diagrams coupled with low $\mathrm{Sr} / \mathrm{Y}, \mathrm{Nb} / \mathrm{Ta}, \mathrm{Zr} / \mathrm{Sm}$, $\mathrm{Zr} / \mathrm{Nb}, \mathrm{K} 2 \mathrm{O} /\left(\mathrm{Na}_{2} \mathrm{O}+\mathrm{CaO}\right.$ ratios (see figs $\left.7 \mathbf{a}, \mathbf{b}, \mathbf{c}\right)$ suggest low-pressure (10-12 kbar) melting of chondritic to enriched basaltic source with residual hornblende and plagioclase. On contrary the high- $\mathrm{Al}_{2} \mathrm{O}_{3}$ gneisses show lower $\mathrm{SiO}_{2}$ (61-72 wt\%) with high $\mathrm{Ba}-\mathrm{Sr}$, low total REE (68$153 \mathrm{ppm})$, weak to strongly fractionated REE patterns $\left.\left[(\mathrm{La} / \mathrm{Yb})_{\mathrm{N}}=2.4-33.7\right)\right]$ without $\mathrm{Eu}$ anomalies (see Fig. 13c in supplementary file) coupled with strong negative $\mathrm{Nb}$-Ta-Ti but positive Sr anomalies spider diagrams (see fig.13d in supplementary file). This coupled with higher $\mathrm{Sr} / \mathrm{Y}, \mathrm{Nb} / \mathrm{Ta}, \mathrm{Zr} / \mathrm{Sm}, \mathrm{Sr} / \mathrm{Y}, \mathrm{K}_{2} \mathrm{O} /\left(\mathrm{Na}_{2} \mathrm{O}+\mathrm{CaO}\right.$ (see figs.7 a, b, c) indicate moderate 
pressure melting (12-15 Kbar) of mafic source with hornblende, garnet-ilmenite $( \pm)$ in residue. Experimental constraints refined melting conditions for origin of TTGs ${ }^{53}$ also indicate $12-15$ kbar for garnet to stabilize in the residue.

In-situ Hf isotope [ ${ }_{\varepsilon} \mathrm{Hf}_{(\mathrm{T})} 2.1$ to 3.7] of 3350-3300 Ma gneisses (see fig. 8) indicate their origin from short lived mafic crust with minor ancient crustal input which is in confirmity with published $\mathrm{Nd}$ isotope $\left[\varepsilon \mathrm{Ed}_{(\mathrm{T})}=-0.6\right.$ to $\left.2.1 ;{ }^{31}\right]$.

Melting of subducting oceanic crust originated at spreading centre can be ruled out as such source is depleted and cannot explain high content of incompatible elements of the $\mathrm{TTGs}^{31,47-48,59}$. On the other hand, their origin could be attributed to either melting of the oceanic plateau crust or oceanic arc crust in the realm of horizontal motion of stagnant lid crust. Melting of oceanic plateau crust (similar to associated $>3350$ Ma komatiites or komatiite basalts) generate melts depleted in incompatible elements and require large scale differentiation to explain high incompatible element contents of TTGs. Further, no evidence for melting of associated komatiites preserved despite they form keels and interlayered with high-pressure assemblages (garnet-kyanite). Alternatively, enriched mafic rocks of oceanic arc crust generated by shallow subduction of rocks making up a stagnant lid beneath volcanic plateau or built on substrate of ancient ( $>3600 \mathrm{Ma})$ crust can be considered. Moderate (12-15 kbar) melting of enriched mafic arc crust can generate TTGs melts with stable hornblendeplagioclase \pm garnet \pm ilmenite in residue. The 3350-3300 Ma gneisses appears to be subcontemporaneous with volcanism in the Northcentral block as revealed by $3305 \pm 10 \mathrm{Ma}$ pyroclastic felsic lava flows from the higher stratigraphic level. This sub-contemporaneous nature together with petrological data like increasing pressures from lower pressure in north (chlorite-chloritoid-garnet) higher pressure to the south (kyanite-garnet in contact) along the contact zone between Northcentral to Southwestern block imply southward convergence 
probably built oceanic arc. Melting of newly formed oceanic arc crust at different depths could generate the 3350-3300 Ma gneisses.

\section{Northcentral block: ca.3430 Ma TTGs}

TTGs adjoining to the greenstone sequences exhibit high $\mathrm{SiO}_{2}(72-74 \mathrm{wt} \%)$, low-Al $(<14.6 \mathrm{wt} \%)$, low to moderate $\mathrm{Ba}$, Sr, total REE $(113-185 \mathrm{ppm})$ with poor to moderately fractionated REE (Fig.14a in supplementary file) patterns $\left[(\mathrm{La} / \mathrm{Yb})_{\mathrm{N}}=4.4-19.1\right]$ with moderate $\mathrm{Eu}$ anomalies $\left(\mathrm{Eu} / \mathrm{Eu}^{*}=0.41\right.$ to 0.70$)$. These characteristics together with less pronounced negative Nb-Ta-Ti anomalies (Fig.14b in supplementary file) on spider diagrams and coupled low $\mathrm{Sr} / \mathrm{Y}$ (2.8 to 14.4), low $\mathrm{Nb} / \mathrm{Ta}, \mathrm{Sr} / \mathrm{Y}, \mathrm{Zr} / \mathrm{Sm}, \mathrm{Zr} / \mathrm{Nb}, \mathrm{K}_{2} \mathrm{O} / \mathrm{Na}_{2} \mathrm{O}+\mathrm{CaO}$ ratios (see fig. 7a, b,c) argue for low to moderate pressure melting (10 -14 kbar) of mafic source. In-situ zircon Hf isotope data [ ${ }_{\varepsilon} \mathrm{Hf}_{(\mathrm{T})} 2.3$ to 3.1] is in conformity with trace element data indicating chondritic to slightly depleted mafic source (see fig. 8).

\section{Eastern block: ca.3289-3276 Ma TTGs}

Published data ${ }^{31,43}$ reveal younger ages of 3289 -3276 Ma for tonalitic to granodioritic gneisses. Majority of the samples (except one sample) belong to low-Al $(<14.3 \mathrm{wt} \%)$ group which show high $\mathrm{SiO}_{2}(70-76 \mathrm{wt} \%)$ have low $\mathrm{Ba}-\mathrm{Sr}$, REE (13-111 ppm) with poorly fractionated (Fig. 15a in supplementary file) REE patterns $\left[(\mathrm{La} / \mathrm{Yb})_{\mathrm{N}}=2.3-5.6\right]$ and variable $\mathrm{Eu}$ $\left(\mathrm{Eu} / \mathrm{Eu}^{*}=0.50-1.36\right)$ and negative $\mathrm{Nb}-\mathrm{Ti}$ but positive $\mathrm{Ta}$ and $\mathrm{Y}$ anomalies (Fig.15b in supplementary file). These characteristics together with sub-chondritic $\mathrm{Nb} / \mathrm{Ta}, \mathrm{Sr} / \mathrm{Y}, \mathrm{Zr} / \mathrm{Sm}$, $\mathrm{K}_{2} \mathrm{O} / \mathrm{Na}_{2} \mathrm{O}+\mathrm{CaO}$ ratios (see fig.7a,b,c) could be attributed to their derivation by low pressure (10-12 kbar) melting of depleted to chondritic mafic source which is in agreement with their incompatible element contents and in-situ zircon $\mathcal{E H f}_{(\mathrm{T})}=+3.1$ to $+3.5^{43}$ and whole rock $\mathrm{ENd}_{(\mathrm{T})}$ $=0.3$ to $1.8^{31}$. 

trondhjemites ca. 3230-3177 $\mathrm{Ma}^{31-32,43}$. They exhibit high-Al (>15.0 wt\%) except three samples showing low-Al (<14 wt\%). Elemental characteristics like high Ba (371-724 ppm),

Sr (322-735 ppm), low to moderate total REE (32-237 ppm) and moderate to highly fractionated REE $\left[(\mathrm{La} / \mathrm{Yb})_{\mathrm{N}}=8.07-85.44\right.$, Fig.16a in supplementary file $)$, strong negative $\mathrm{Nb}$ Ti anomalies but positive or negative Sr-Y anomalies (Fig. 16b in supplementary file) indicate their origin from mafic sources at different depths. These characteristics together with high $\mathrm{K}_{2} \mathrm{O} /\left(\mathrm{Na}_{2} \mathrm{O}+\mathrm{CaO}\right.$ ) but low $\mathrm{Nb} / \mathrm{Ta}, \mathrm{Zr} / \mathrm{Nb}, \mathrm{Zr} / \mathrm{Sm}, \mathrm{Sr} / \mathrm{Y}$, (see figs.7a,b,c) argue for moderate to high pressure melting (12-17 kbar) with hornblende, garnet, and ilmenite in source residue. Whole rock $\mathrm{Nd}$ isotope $\left[{ }_{\varepsilon} \mathrm{Nd}_{(\mathrm{T})}=0.4\right.$ to 1.0$]$ and in-situ $\mathrm{Hf}\left({ }_{\varepsilon} \mathrm{Hf}_{(\mathrm{T})}=+2.1\right)$ data (see fig.8) suggest derivation of trondhjemite from short-lived mantle-derived mafic source.

\section{Emplacement of diapiric trondhjemites and assembly of three tectonic blocks}

The identification of the three distinct tectonic units in the Holenarsipur greenstone belt with independent histories is a very important discovery because their assembly into cratonic framework requires some sort of horizontal motion during Paleoarchean. In addition, the basement TTGs gneisses adjoining to Southwestern block exhibit ages ranging ca. $3430 \mathrm{Ma}$ to $3300 \mathrm{Ma}$ (remnants upto $3600 \mathrm{Ma}$ ), whilst 3430-3339 Ma adjoining to Northcentral block and 3285-3276 Ma to the western margin of the Eastern block. Strain fabrics data and U-Pb zircon ages indicate that assembly of the three tectonic units (greenstone and adjoining TTGs) coinciding with the emplacement of ca 3230-3177 Ma diapiric trondhjemites, therefore, indicating horizontal motion following terminal stage (ca. $3376 \mathrm{Ma}$ ) accretion of the basement. There is a consensus on the fact that majority of the Archean TTGs formed by low to medium pressure hydrous melting of young basaltic precursors with stable amphibole and/or garnet $( \pm$ plagioclase, \pm ilmenite) in residue ${ }^{25,60}$. These conditions are necessary to account for the 
mineralogy and geochemistry of TTGs. However, the geological and tectonic process that allows these conditions to be reached is still a matter of debate (e.g. $\left.{ }^{4,8,56-57}\right)$. The ideal candidate among known, and clearly identified geological processes is subduction because it can bring material down into the mantle depth at rates fast enough to avoid complete dehydration of the slab before reaching the hydrous solidus of wet basalt. However, rheological parameters of the Eoarchean to Paleoarchean crust do not seem to be in favor of plate tectonics (e.g., ${ }^{61}$ ). Nevertheless, alternative models for plate tectonics exist and invoke horizontal motions that would result in either intermittent subduction ${ }^{62}$, formation of slices that pile downward ${ }^{63}$, or formation of duplex structures ${ }^{9}$. Most recent numerical modeling also propose that some localized horizontal motions can develop at the margin of massive mantle plumes (e.g., ${ }^{6,58}$ ) which could reconcile many of contradictory observations and fit in a fair amount of Archean tectonic models involving both vertical and horizontal motions (e.g., ${ }^{4,12,48,55,59,64}$ ). Sagduction is a vertical tectonic process clearly identified in the Archean (e.g., ${ }^{27,65-66}$ ) that could possibly replace the need for horizontal tectonics (e.g., ${ }^{67}$ ). In addition, proposed sources for the formation of TTGs match well with tholeiitic basalts present in greenstone belts (e.g., ${ }^{60,68}$ ). However, no clear evidence for partial melting of sinking greenstone belts has been presented so far. As mentioned earlier, the western Dharwar craton presents a continuous tilted crustal panel corresponding upper to lower crust which, hence, allows the sinking of high-density greenstones to be followed. Yet, sinking greenstones exhibit a continuous increase in metamorphic grade until granulite facies (e.g., ${ }^{42,69}$ ) without evidence for in-situ partial melting. This could indicate that greenstone sinking rates are too low to counterbalance dehydration reaction rates and, in turn, imply that mafic lithologies would be anhydrous by the time they reach their wet solidus.

Our model for the origin of Paleoarchean continental core in Holenarsipur region involves formation of oceanic volcanic plateaus close to a microcontinent remnant prior to 
$3400 \mathrm{Ma}$ (Southwestern block), followed by plume fed oceanic crust similar to modern spreading centre ca. 3400 Ma (Eastern block) and its horizontal motion with eventual convergence beneath micro-volcanic plateau resulted in the formation of oceanic arc (Fig.9). Melting of oceanic arc crust at different depths produce magmatic precursors of ca. 3350-3270 Ma TTGs. Assembly of oceanic arc with oceanic plateau and adjoining (>3500 Ma) microcontinent in the context of shallow angle subduction with eventual slab break off ca. 3230 Ma caused mantle upwelling beneath arc crust/plateau led to moderate to high pressure (12-17 kbar) melting resulted in generation of hot trondhjemite magmas. Emplacement of these trondhjemite magmas cause softening of felsic crust leading to partial convective overturn driven gravitational instabilities, collapse of high density volcanics into low density felsic resulting in development of dome-keel structures, culminated with metamorphism and craton formation ca. $3100 \mathrm{Ma}$ (see fig.9). This model of diachronous evolution involving both vertical addition of juvenile materials and horizontal motion is in conformity with the documented accretion patterns, strain fabrics and metamorphic record (e.g., $\left.{ }^{29}\right)$.

\section{Origin of cratonal core in the Western Dharwar Craton and Archean geodynamics}

The identification of the three genetically unrelated tectonic elements in the cratonal core of WDC and their assembly is a very important discovery because this requires some sort of horizontal motion to gather these distinct tectonic elements in one location. In addition, the surrounding granitoid basement exhibit ages between the oldest component and that of final assembly ca.3200 Ma, therefore, indicating a possible link between the gathering process and the formation of the granitoids that make up the basement. Therefore, our favorite model for the formation of Archean cratons is, that vertical motions in mantle upwelling zones prior to $3400 \mathrm{Ma}$ caused melting of the base of a (stagnant) oceanic plateau lid in mantle upwelling zones whilst horizontal motion initiated temporarily in the Paleoarchean ca.3350 Ma, and 
perhaps the Hadean, and it was induced by boundary forces linked to the emplacement of large mantle plumes together with eruption of massive amounts of lava at the surface. Horizontal density contrasts facilitated the triggering of proto-subduction (e.g., duplex, downward piling of slices) by decoupling of tectonic elements such as oceanic crust and oceanic plateaus (e.g. $\left.{ }^{70}\right)$. The above lines of arguments suggest that crustal fragments making up the WDC accreted through vertical motions during Eoarchean to Paleoarchean and subsequently assembled by horizontal motion of intervening (stagnant) oceanic plateau lid, eventual subduction and slab breakoff leading to generation of hot felsic magmas. Emplacement of these felsic magmas cause rheological weakening of lithosphere causing inverse density stratification, development of dome and keel structures, high T/P metamorphism resulting in craton formation.

The formation of Archean basement granitoids have been explained by oceanic crust reworking in places such as South Africa (e.g., ${ }^{10,71}$ ) and Greenland ${ }^{11,13}$, whereas in Pilbara ${ }^{57,72}$ and Karelia ${ }^{22}$ it has been argued to originate by reworking of oceanic plateau. The Western Dharwar craton presents characteristics and the differences observed among Archean cratons can certainly arise from distinct abundances of involved lithological units as well as their ages because long-term accumulation of evidence suggests that the global geodynamics evolved throughout the Archean to progressively to initiate modern-style plate tectonics ${ }^{8}$. There is also much debate in these localities between tectonic regimes (stagnant lid versus horizontal tectonics) but the Western Dharwar example illustrates that horizontal tectonics is necessary to assemble distinct tectonic blocks but the details regarding the origin of this horizontal motion remains uncertain. It may be, for instance, plume related (e.g., ${ }^{16}$ ), spontaneous (e.g., ${ }^{70}$ ), episodic $^{62}$, or scale stacking rather than actual subduction ${ }^{59}$ but we cannot conclude on this aspect. 


\section{References}

1. Sleep, NH. Edge-modulated stagnant-lid convection and volcanic passive margins. Geochem. Geophys. Geosyst. 8 (12), 1-15 (2007).

2. Brown, M., Johnson, T., Gardiner, NJ. Plate tectonics and the Archean Earth. Ann. Rev. Earth Planet. Sci. 48 (2020).

3. Moore, WB., Webb, AAG., Heat-pipe earth. Nature 501 (7468), 501-505 (2013).

4. Bédard, J.H., Stagnant lids and mantle overturns: implications for Archaean tectonics, magmagenesis, crustal growth, mantle evolution, and the start of plate tectonics. Geosci. Front. 9, 19-49 (2018).

5. Sobolev, AV., Asafor, EV., Gurenko, AA., Arndt, NT., Batanova, VG., Portnuagin, MV., GarbeSchonberg, D., Wilson, AH., Byerly, GR., Deep hydrous mantle reservoir provides evidence for crustal recycling before 3.3 billion years. Nature 571 (7766), 555-559 (2019).

6. Baes, M., Gerya, T., Sobolev, S.V., 3-D thermo-mechanical modelling of plume induced subduction initiation. Earth Planet. Sci. Lett. 453, 193-203 (2016).

7. Ernst, RE., Bleeker, W., Hamilton, MA, Soderlund, U., Chamberlain, KR, Sylverster, PJ., Completing the plate tectonic revolution: a project to reconstruct pre-Pangea supercontinents using the large igneous province (LIP) record. Geological Society of America abstracts with programs 41(7), pp 368 (2009).

8. Moyen J-F, Laurent O. Archaean tectonic systems: a view from igneous rocks. Lithos 302-303:99-125 (2018).

9. Komiya, T. et al., Geology of the Eoarchean, N 3.95 Ga, Nulliak supracrustal rocks in the Saglek Block, northern Labrador, Canada: The oldest geological evidence for plate tectonics, Tectonophys. 662, 40-62 (2015).

10. Grosch EG, Slama J. Evidence for 3.3-billion-year-old oceanic crust in the Barberton greenstone belt, South Africa. Geology 45, 695-698 (2017).

11. Bridgwater, D., McGregor, V. R. \& Myers, J. S. A horizontal tectonic regime in the Archaean of Greenland and its implications for early crustal thickening. Precam. Res. 1, 179-197 (1974).

12. Choukroune, P., Ludden, J.N., Chardon, D., Calvert, A.J., Bouhallier, H., Archaean crustal growth and processes: a comparision of the Superior province and the Dharwar craton India. In: Burg, J.P., Ford, M. (Eds.), Orogeny Through Time, Geol. Soc. Spec. Publi. 121, 63-98 (1997).

13. Polat, A., Appel, P.W.U., Fryer, B.J., An overview of the geochemistry of Eoarchean to Mesoarchean ultramafic to mafic volcanic rocks, SW Greenland: implications for mantle depletion and petrogenetic processes at subduction zones in the early Earth. Gond. Res. 20 (2-3), 255-283 (2011).

14. Bédard, J.H., Harris, L.B., Thurston, P., The hunting of the snArc. Precam. Res. 229, $20-48$ (2013).

15. Calvert, A. J., Sawyer, E. W., Davis, W. J. \& Ludden, J. N. Archaean subduction inferred from a mantle suture in the Superior Province. Nature, 375, 670-674 (1995).

16. Gerya, T., Stern, R.J., Baes, M., Sobolev, S.V., Whattam, S.A., Plate tectonics on the Earth triggered by plume-induced subduction initiation. Nature $\mathbf{5 2 7}$ (7577), 221-225 (2015).

17. Rozel, A. B., Golabek, G. J., Jain, C., Tackley, P. J., \& Gerya, T. Continental crust formation on early Earth controlled by intrusive magmatism. Nature, 545(7654), 332-335 (2017).

18. Pearce, J.A., Geochemical fingerprinting of oceanic basalts with applications to ophiolite classification and the search for Archean oceanic crust. Lithos 100, 14-48 (2008).

19. Arndt, N., The formation and evolution of the continental crust. Geoche. Pers. 2 (3), pp.405 (2013).

20. Johnson TE, Kirkland CL, Gardiner NJ, Brown M, , Smithies, R.H., Santosh, M., Secular change in TTG compositions: Implications for the evolution of Archaean geodynamics. Earth Planet. Sci. Lett. 505, 65-75 (2019).

21. Smithies, R.H., et al., No evidence for high pressure melting of Earth's crust in the Archean. Nat. Comm. 10 (5559), (2019).

22. Puchtel, I.S., et al., Petrology and geochemistry of crustally contaminated komatiitic basalts from the Vetreny Belt, south eastern Baltic Shield: Evidence for an early Proterozoic mantle plume beneath rifted Archean continental lithosphere. Geochim. Cosmochim. Acta, 61, 1205-1222 (1997).

23. Groves, D. I., Archibald, N. J., Bettenay, L. F. \& Binns, R. A. Greenstone belts as ancient marginal basins or ensialic rift zones. Nature, 273, 460-461 (1978).

24. Anheeusser, C.R., Archean greenstones and associated granitic rocks - a review. J. Af. Earth Sci. 100, 684-732 (2014).

25. Moyen, J.-F., Martin, H., Forty years of TTG research. Lithos 148, 312-336 (2012).

26. Kaczmarek, M.A., Reddy, S.M., Nutman, A.P., Friend, C.R.L., Bennett, V.C., Earth's oldest mantle fabrics indicate Eoarchaean subduction. Nat. comm. 7 (10665) (2016). 
27. Bouhallier, H., Chardon, D. and Choukroune, P., Strain patterns in Archaean dome-and-basin structures: the Dharwar craton (Karnataka, South India). Earth Plane. Sci. Lett. 135, 57-75 (1995).

28. Chardon, D., Jayananda, M., Chetty, T.R.K., Peucat, J-J., Precambrian continental strain and shear zone patterns: the South Indian case. J. Geophys. Res. Solid Earth 113, B08402 (2008).

29. Jayananda, M., Santosh M., Aadhiseshan, K. R., Formation of Archean continental crust in the Dharwar craton, Southern India. Earth Sci. Rev. 181, 12-42 (2018).

30. Radhakrishna, B.P., Naqvi, S.M., Precambrian continental crust of India and its evolution. J. Geol. 94, 145-166 (1986).

31. Jayananda, M., Chardon, D., Peucat, -J.-J., Fanning, C.M., Paleo- to Mesoarchean TTG accretion and continental growth, western Dharwar craton, southern India: SHRIMP U-Pb zircon geochronology, whole-rock geochemistry and Nd-Sr isotopes. Precam. Res. 268, 295-322 (2015).

32. Guitreau, M., Mukusa, S.B., Loudin, L., Krishnan, S., New constraints on early formation of western Dharwar craton (India) from igneous zircon U-Pb and Lu-Hf isotopes. Precam. Res. 302: 33-49 (2017).

33. Bouhallier, H., Choukroune, P. and Ballèvre, M., Diapirism, bulk homogeneous shortening and transcurrent shearing in the Archaean Dharwar craton: the Holenarsipur area, southern India. Precam. Res. 63, 43-58 (1993).

34. Nutman, AP., Chadwick, B., Ramakrishnan, M., Viswanatha, MN. SHRIMP U-Pb ages of Detrital Zircon in Sargur Supracrustal Rocks in Western Karnataka, Southern India. J. Geol. Soc. India 39, 367374 (1992).

35. Meen JK, Rogers JJ, Fullagar PD Lead isotopic composition of the Western Dharwar Craton, Southern India: evidence for distinct middle Archaean terrenes in a late Archaean Craton. Geochim. Cosmochim. Acta 56, 2455-2470 (1992).

36. Jayananda, M., et al., Physical volcanology and geochemistry of Palaeoarchaean komatiite lava flows from the western Dharwar craton, southern India: implications for Archaean mantle evolution and crustal growth. Int. Geol. Rev. 58-13, 1569-1595 (2016).

37. Peucat, J.-J., Bouhallier, H., Fanning, C.M., Jayananda, M., Age of Holenarsipur schist belt, relationships with the surrounding gneisses (Karnataka, south India). J. Geol. 103, 701-710 (1995).

38. Naqvi, S.M., Ram Mohan, M., Rana Prathap, J.G., Srinivasa Sarma, D., Adakite-TTG connection and fate of Mesoarchaean basaltic crust of Holenarsipur nucleus, Dharwar Craton, India. J. Asian Earth Sci. 35, 416-434 (2009).

39. Kunugiza, K., Kato, Y., Kano, T., Takaba, Y., Kuruma, I., Sohma, T., 1996. An Archean tectonic model of the Dharwar craton, southern India: the origin of the Holenarasipur greenstone belt (Hassan district, Karnataka) and reinterpretation of the Sargur-Dharwar relationship. J. Asian Earth Sci. 14 (34), 149-160 (1996).

40. Swami Nath, J., Ramakrishnan, M., Early Precambrian supracrustals of Southern Karnataka. Geol. Surv. India Mem., 112, 308p (1981).

41. Naqvi SM, Allen P, Condie KC Geochemistry of some unusual early Archaean metasediments from Dharwar Craton, India. Precam. Res 22, 125-147 (1983).

42. Jayananda, M., et al., Geochronological constraints on Meso-neoarchean regional metamorphism and magmatism in the Dharwar craton, southern India. J. Asian Earth Sci. 78, 18-38 (2013a).

43. Ranjan, S., Upadhyay, D., Abhinay, K., Srikantappa, C., Paleoarchean and Neoarchean TonaliteTrondhjemite-Granodiorite (TTG) and granite magmatism in the Western Dharwar Craton, southern India: implications for Archean continental growth and geodynamics. Precam. Res. 105630 (2020).

44. Condie, K.C., 2003. Incompatible element ratios in oceanic basalts and komatiites: Tracking deep mantle sources and continental growth rates with time. Geochem. Geophys. Geosyst.4 (1), 1005 (2003).

45. Feng, R., Kerrich, R., Geochemical evolution of granitoids from the Archean Abitibi Southern volcanic zone and the Pontiac subprovince, Superior Province, Canada: Implications for tectonic history and source regions. Chem. Geol. 98 (1-2), 23-70 (1992).

46. Rollinson, H., Coupled evolution of Archean continental crust and subcontinental lithospheric mantle. Geology 38, 1083-1086 (2010).

47. Hoffmann, J. E \& MüNker, C, Polat, A. \& Rosing, Minik \& Schulz, Toni. The origin of decoupled Hf$\mathrm{Nd}$ isotope composition in Eoarchean rocks from southern West Greenland. Geochim. Cosmochim. Acta. 75. 6610-6628 (2011).

48. Martin, H., Moyen, J.-F., Guitreau, M., Blichert-Toft, J., Le Pennec, J.-L., Why Archean TTG cannot be generated by MORB melting in subduction zone. Lithos 198-199, 1-13 (2014).

49. Barker F, Arth JG., Generation of trondhjemite-tonalite liquids and Archean bimodal trondhjemitebasalt suites. Geology 4 596-600 (1976).

50. Jahn, B., Glikson, A.Y., Peucat, J.-J., Hickman, A.H., REE geochemistry and isotopic data of Archean silicic volcanics and granitoids from the Pilbara block, Western Australia: implications for early crustal evolution. Geochim. Cosmochim. Acta 45, 1633-1652 (1981). 
51. Moyen, J.-F., The composite Archean grey gneisses: petrological significance, and evidence for a nonunique tectonic setting for Archean crustal growth. Lithos 124 (1-2), 21-36 (2011).

52. Gale, A., Dalton, C.A., Langmuir, C.H., Su, Y., Schilling, J.G., The mean composition of ocean ridge basalts. Geochem. Geophys. Geosyst. 14-3, 489-518 (2013).

53. Moyen, J., Stevens, G., Experimental constraints on TTG petrogenesis: implications for Archean geodynamics. In: Been, K., Mareschal, J.-C., Condie, K.C. (Eds.), Archean Geodynamics and Environments. American Geophysical Union Monograph, Washington, DC. 149-175 (2006).

54. Adams, J., Rushmer, T., O’Neil, J., Francis, D., Hadean greenstones from Nuvvuagittuq fold belt and origin of the early continental crust. Geology, 40,363-366 (2012).

55. Guitreau, M., Blichert-Toft, J., Martin, M., Mojzsis, S.J., Albarède, F., Hafnium isotope evidence from Archean granitic rocks for deep-mantle origin of continental crust. Earth Planet. Sci. Lett. 337-338, 211-223 (2012).

56. Johnson TE, Brown M, Gardiner NJ, Kirkland CL, Smithies, R.H 2017. Earth's first stable continents did not form by subduction. Nature, 543(7644): 239-242 (2017).

57. Smithies, R.H., Champion, D.C., Van Kranendonk, M.J., Formation of Paleoarchean continental crust through infracrustal melting of enriched basalt. Earth Planet. Sci. Lett. 281 (3-4), 298-306 (2009).

58. Gerya, T., Precambrian geodynamics: concepts and models. Gond. Res. 25, 442-463 (2014).

59. Nagel, T.J., Hoffmann, J.E., Münker, C., Generation of Eoarchean tonalite-trondhjemite-granodiorite suite from melting thickened mafic arc crust. Geology 40, 375-378 (2012).

60. Nédélec, A., Chevrel, M.O., Moyen, J.F., Ganne, J., Fabre, S., TTGs in the making: Natural evidence from Inyoni shear zone (Barberton, South Africa), Lithos, 153, 25-38 (2012).

61. Rey, P.F., Coltice, N., Neoarchean lithospheric strengthening and the coupling of Earth's geochemical reservoirs. Geology 36, 635-638 (2008).

62. Van Hunen, J., Moyen, J.-F., Archean subduction: fact or fiction? Ann. Rev. Earth Planet. Sci. 40, 195219 (2012).

63. de Wit, M.J., On Archean granites, greenstones, cratons and tectonics: does the evidence demand a verdict? Precam. Res. 91 (1-2), 181-226 (1998).

64. Jayananda, M., Kano, T., Peucat, J.-J., Channabasappa, S., 3.35 Ga komatiite volcanism in the western Dharwar craton: constraints from $\mathrm{Nd}$ isotopes and whole rock geochemistry. Precam. Res. 162, 160-179 (2008).

65. Gorman, B. E., Pearce, T. H. \& Birketre, T. C. On the structure of Archaean greenstone belts. Precam. Res., 6, 23-41 (1978).

66. Chardon, D., Choukroune, P., Jayananda, M., Strain patterns, de'collement and incipient sagducted greenstone terrains in the Archaean Dharwar craton (south India). J. Struct. Geol. 18, 991-1004 (1996).

67. Van Kranendonk, M.J., Kröner, A., Hoffmann, J.E., Nagel, T., Anhaeusser, C.R., Just another drip: reanalysis of a proposed Mesoarchean suture from the Barberton Mountain Land, South Africa. Precam. Res. 254, 19-35 (2014).

68. Rapp, R.P., Watson, E.B., Dehydration melting of metabasalt at 8-32 kbar: implications for continental growth and crust-mantle recycling. J. Petrology 36, 891-931 (1995).

69. Raase, P., Raith, M., Ackermand, D., Lal, R.K., Progressive metamorphism of mafic rocks from greenschist to granulite facies in the Dharwar craton of South India. J. Geol. 94, 261-282 (1986).

70. Nair, R., Chacko, T., Role of oceanic plateaus in the initiation of subduction and origin of continental crust. Geology 36 (7), 583-586 (2008).

71. Moyen, J., Stevens, G., Kisters, A., 2006. Record of mid-Archaean subduction from metamorphism in the Barberton terrain, South Africa. Nature 442 (7102), 559-562 (2006).

72. Van Kranendonk, M.J., Smithies, R.H., Griffin, W.L., Huston, D.L., Hickman, A.H., Champion, D.C., Anhaeusser, C.R., Pirajno, F., Making it thick: a volcanic plateau model for Paleoarchean continental lithosphere of the Pilbara and Kaapvaal cratons. In: Roberts, N.M.W., Van Kranendonk, M., Parman, S., Shirey, S., Clift, P.D. (Eds.), Continent Formation through Time. Geol. Soc. London, Special Publications 389, 83-112 (2015).

73. Jenson LS., A new method of classifying alkali volcanic rocks: Ontario Division Mineral, Miscellaneous Paper, 66:22 (1976).

74. Viljoen MJ, Viljoen FP, Pearton TN The nature and distribution of Archaean komatiite volcanics in South Africa. In: Arndt NT, Nisbet EG (eds) Komatiites. Allen and Unwin, London, 53-79 (1982).

75. Sun, S.-S., McDonough, W.F., Chemical and isotopic systematics of oceanic basalts: implications for mantle composition and processes. In: Saunders, A.D., Norry, M.J. (Eds.), Magmatism in the Ocean Basins. Geol. Soc. London, Special publication 42,313-345 (1989).

76. Polat, A., Hofmann, A.W., and Rosing, M. Boninite-like volcanic rocks in the 3.7-3.8 Ga Isua greenstone belt, West Greenland: Geochemical evidence for intra-oceanic subduction zone processes in the early Earth. Chem. Geol. 184: 231-254 (2002). 
77. Condie, K.C., High field strength element ratios in Archean basalts: a window to evolving sources of mantle plumes: Lithos, 79, 491-504 (2005).

78. Moyen, J-F., High $\mathrm{Sr} / \mathrm{Y}$ and $\mathrm{La} / \mathrm{Yb}$ ratios: the meaning of the "adakitic signature". Lithos 112 (3-4), 556574 (2009).

79. Hoffmann, J.E., Zhang, C., Moyen, JF., Nagel, TJ., The formation of Tonalites-TrondhjemiteGranodiorites in Early continental crust. Earth's Oldest Rocks, $2^{\text {nd }}$ edition, Elsevier. 133-168 (2018).

\begin{abstract}
Acknowledgements:
This work was funded by DST funded projects (ESS/16/334/2007; DST-FIST [SR/FST/ESI146/2016(C)]) and French Agence National de la Recherche through the funded project 'Zircontinents' (ANR-17-CE31-0021) and LabEx ClerVolc (ANR-10-LABX-0006). R. V. Gireesh, Tushipokla and S.V. Balaji Manasa Rao are thanked for their assistance.
\end{abstract}

\title{
Authors contributions:
}

M.J and MG designed the project, generated the data. MJ wrote initial draft of the manuscript and MG contributed to writing the final version. KRA participated in the field work, sample preparation and drafting figures.

T.M and SLC have analyzed samples of greenstone volcanics for elements and $\mathrm{Nd}$ isotopes, and provided intellectual inputs.

Competing financial interests: The authors declare no competing financial interests

\section{Figure captions}

Fig.1. Geological sketch map showing three micro-blocks in the Holenarsipur greenstone belt and adjoining TTGs (with inset map of Peninsular India) showing greenstone units, basement granitoids and diapiric trondhjemite intrusions with age, $\varepsilon \mathrm{Hf}, \varepsilon \mathrm{Nd}$ of the present study; ${ }^{31-32,43}$.

Fig. 2. (a) Eastern block road cut section displaying section of preserved oceanic crust from pillow ultramafic through clays, BIFs, sheeted dykes, plagiogranite, gabbro/norite, layered gabbro with ultramafic and finally peridotite; (b) Interpretative E-W section of preserved oceanic crust. (c) Interpretative vertical section of the oceanic crust

Fig. 3. SW-NE interpretative cross section of crustal panel of Holenarsipur greenstone belt and adjoining basement rocks with distinct lithological assemblages corresponding to three micro-blocks.

Fig.4. (a) $\mathrm{Al}_{2} \mathrm{O}_{3}-\mathrm{Fe}_{2} \mathrm{O}_{3}+\mathrm{TiO}_{2}-\mathrm{MgO}$ ternary plot $^{73}$ showing that volcanics of three greenstone unit are komatiite to komatiite basalt composition (b) $\mathrm{CaO}-\mathrm{MgO}-\mathrm{Al}_{2} \mathrm{O}_{3}$ ternary plot $^{74}$ showing dominant komatiite to komatiite basalt except two samples of Eastern block showing tholeiite composition.

Fig. $5 \mathrm{ENd}(\mathrm{T})$ versus time evolution diagram of greenstone volcanics from three blocks showing involvement of depleted mantle with minor ancient crustal contamination.

Fig.6. (a) $\mathrm{Th} / \mathrm{Yb}$ versus $\mathrm{Nb} / \mathrm{Yb}$ binary plot ${ }^{18}$ indicating primitive to depleted mantle source for the southwestern, northcentral and eastern block (b) $\mathrm{Nb} / \mathrm{Y}$ versus $\mathrm{Zr} / \mathrm{Y}^{77}$ indicating deep depleted to primitive mantle reservoir source for the samples from southwestern, northcentral and eastern block greenstone volcanics. (c) $\mathrm{Zr} / \mathrm{Nb}$ versus $\mathrm{Nb} /$ Th plot $^{77}$ indicating oceanic plateau for SW block, arc to oceanic plateau for North central block and N-MORB to oceanic plateau for Eastern block. Arrows indicate effects of batch melting (F) and subduction (SUB); PM, primitive mantle; DM, shallow depleted mantle; ARC, arc related basalts; NMORB, normal ocean ridge basalt; OIB, oceanic island basalt; DEP, deep depleted mantle; EN, enriched component.

Fig. 7. (a) $\mathrm{Nb} / \mathrm{Ta}$ vs $\mathrm{Zr} / \mathrm{Sm}$ plot ${ }^{47}$ explaining the origin of TTG melt from different source composition, (b) $\mathrm{Nb} / \mathrm{Ta}$ vs $\mathrm{Sr} / \mathrm{Y}$ plot ${ }^{78}$; (c) $\mathrm{K}_{2} \mathrm{O} /\left(\mathrm{Na}_{2} \mathrm{O}+\mathrm{CaO}\right)$ vs $\mathrm{Sr} / \mathrm{Y}$ plot $^{79}$ representing the different pressure level at which the studied 
samples generated from the mantle. Lines correspond to melting models derived from experimental database, as in ${ }^{51,78}$, at different pressures and for two sources, an MORB and a more enriched mafic rock.

650 Fig.8. $\varepsilon_{\mathrm{Hf}}$ versus age diagram for zircons from granitoids exposed within Southwestern, Northcentral and Eastern 651 blocks around the Holenarsipur Belt (Western Dharwar craton). Also shown are the evolution of the depleted mantle, assuming a present day $\varepsilon_{\mathrm{Hf}}$ of +17 , of an arc mantle (present day $\varepsilon_{\mathrm{Hf}}$ of +13 ), of a typical basalt, TTG and zircon formed from an arc mantle at $3700 \mathrm{Ma}$. Values indicated next to the evolution lines of basalt, TTG and zircon correspond to average ${ }^{176} \mathrm{Lu} /{ }^{177} \mathrm{Hf}$. CHUR refers to Chondritic Uniform Reservoir.

Fig.9. Proposed tectonic model for origin of Paleoarchean cratons: (a) Formation of plume fed volcanic plateau on stagnant lid ca. $>3500$ Ma close to remnant of micro-continent; (b) Continued plume impact caused low pressure melting of stagnant lid to produce magmatic precursors of 3500-3400 Ma TTGs; (c) Initiation of oceanic spreading centre in the east during 3400-3350 Ma caused horizontal motion of stagnant lid with eventual subduction beneath volcanic plateau resulted in the development oceanic island arc system; (d) Continued subduction with accumulation hot magmas (generated at greater depth) at the base of arc crust cause melting of arc crust at different depth producing TTG magmas during ca. 3350-3270 Ma; (e) Continued subduction with assembly of oceanic crust, island arc and volcanic plateau and eventual slab breakoff lead to the asthenosphere upwelling caused melting of lower crust/upper most mantle generated hot trondhjemite magmas during ca.3200 $\mathrm{Ma}$; emplacement hot trondhjemite magmas into crust caused partial convective overturn soften crust leading formation of dome and keel structure followed by metamorphism and cratonization ca. 3200-3150 Ma. 
Fig. 1

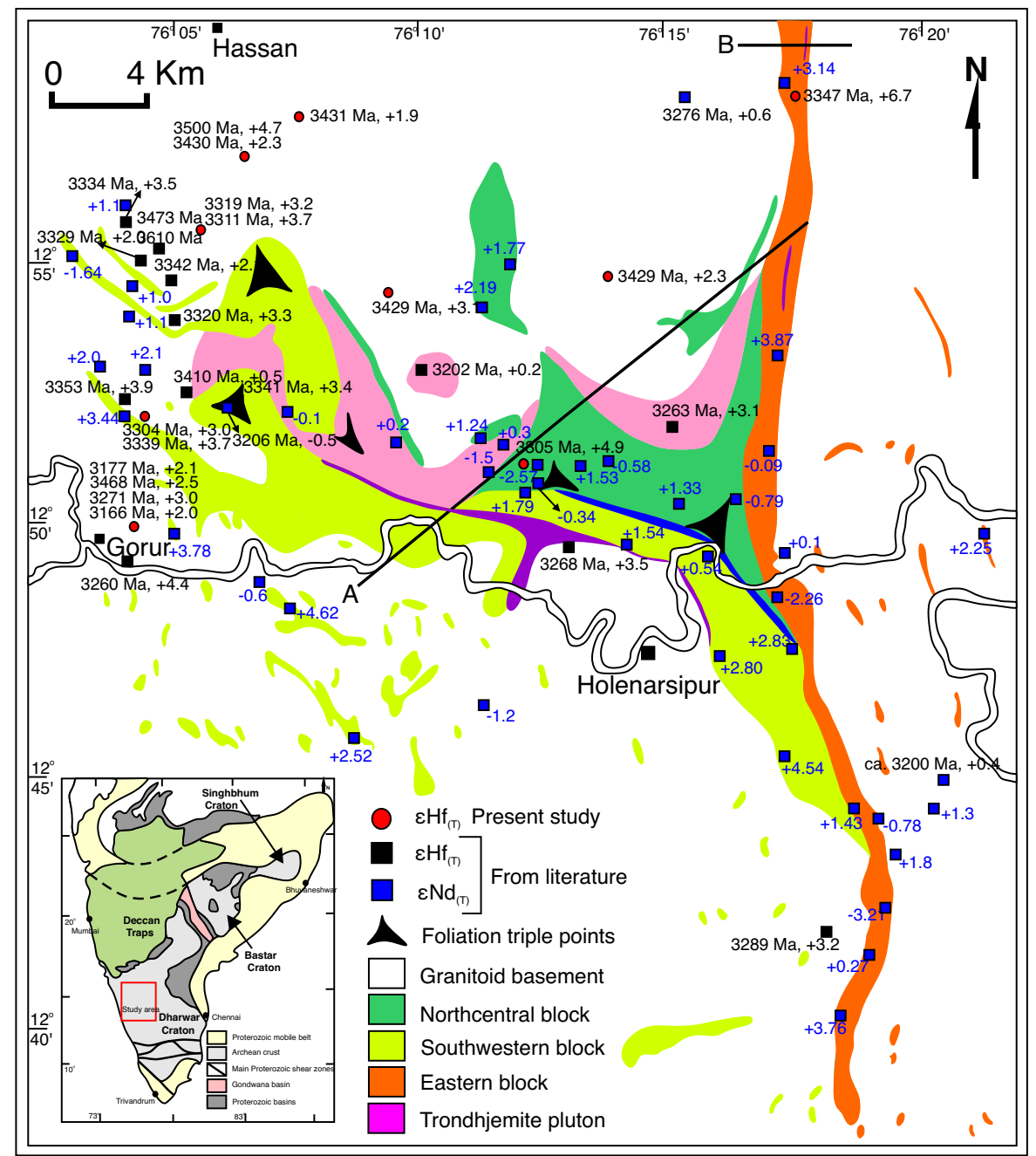

Fig. 2

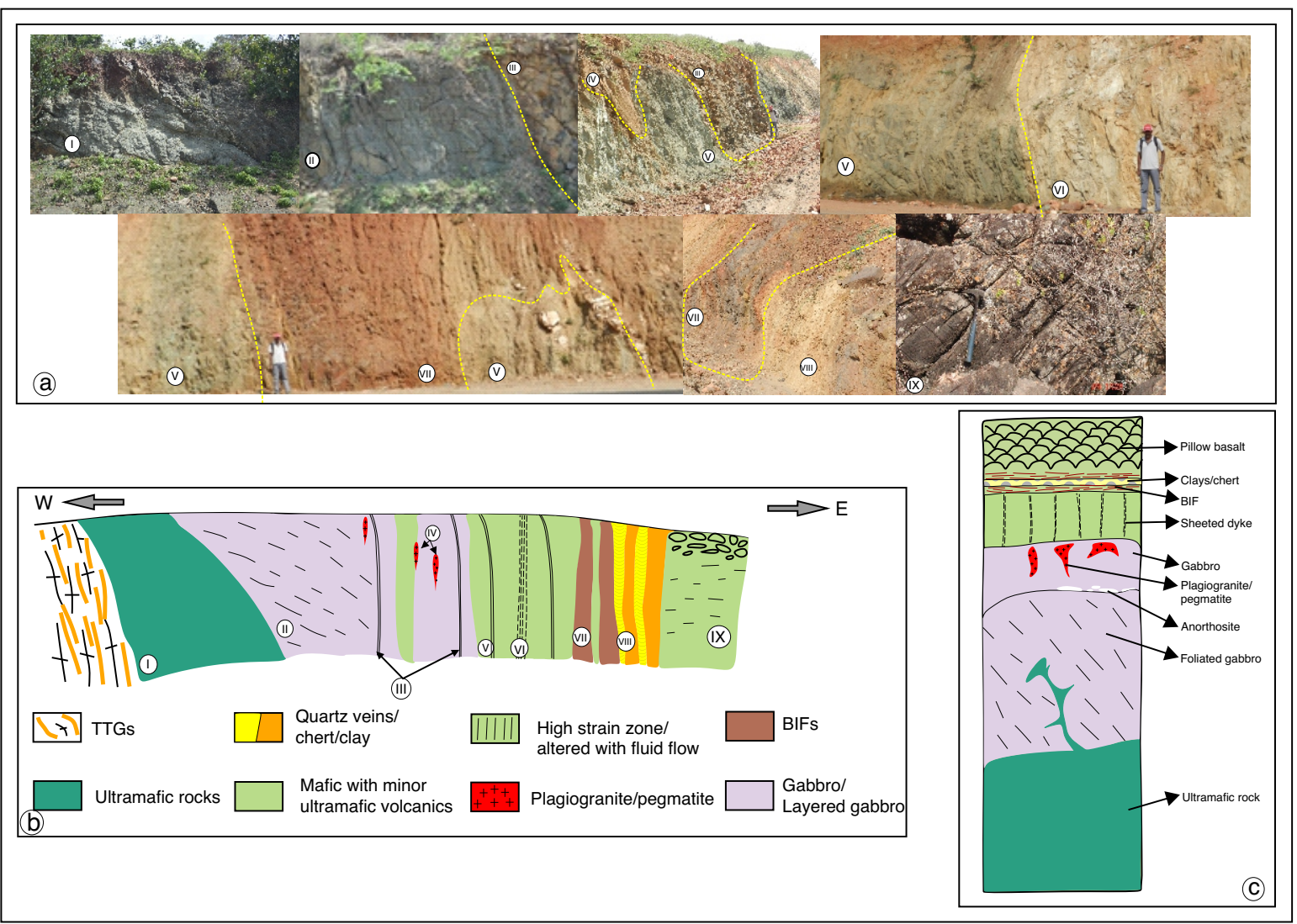



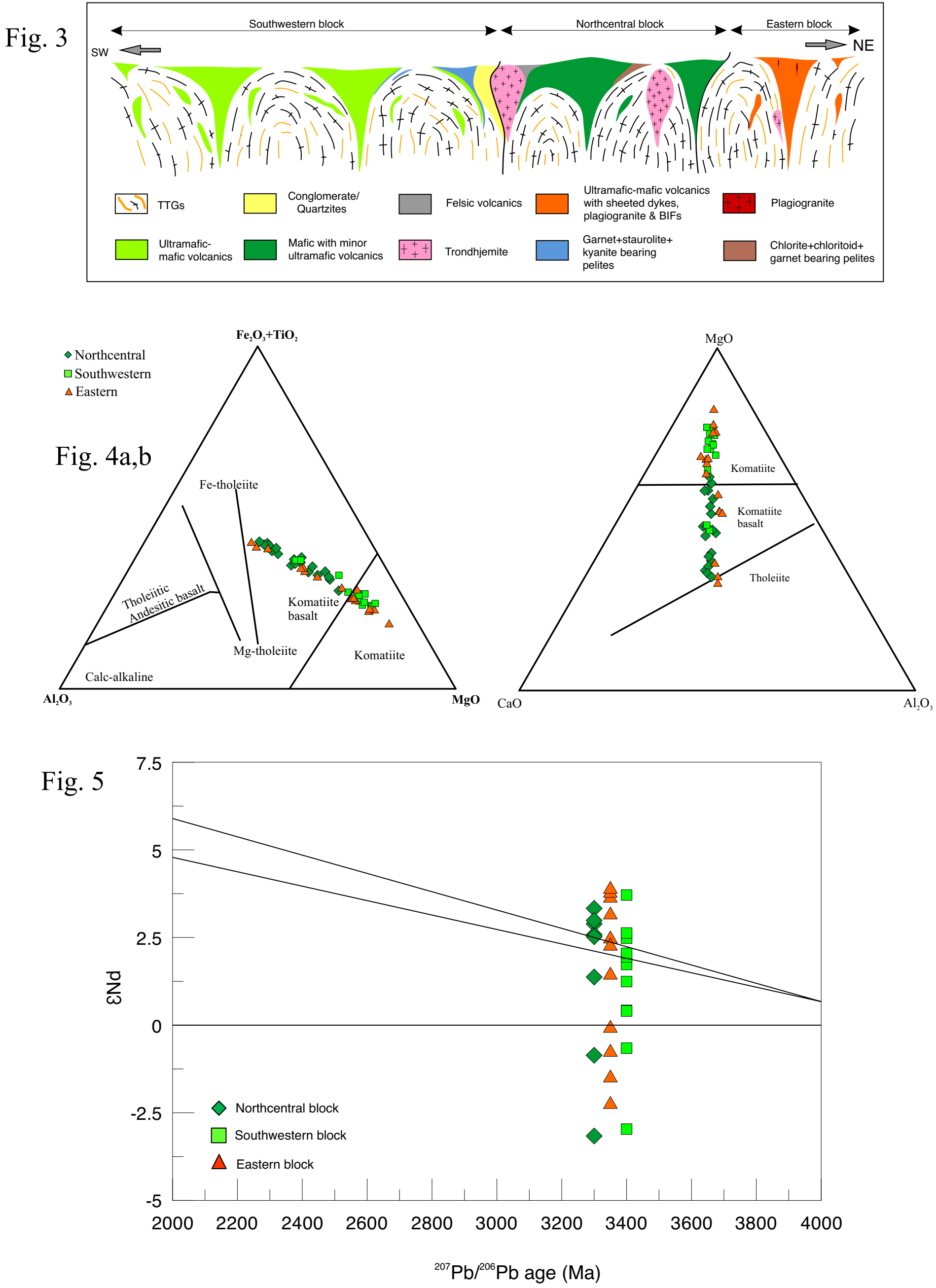
Fig. 6a

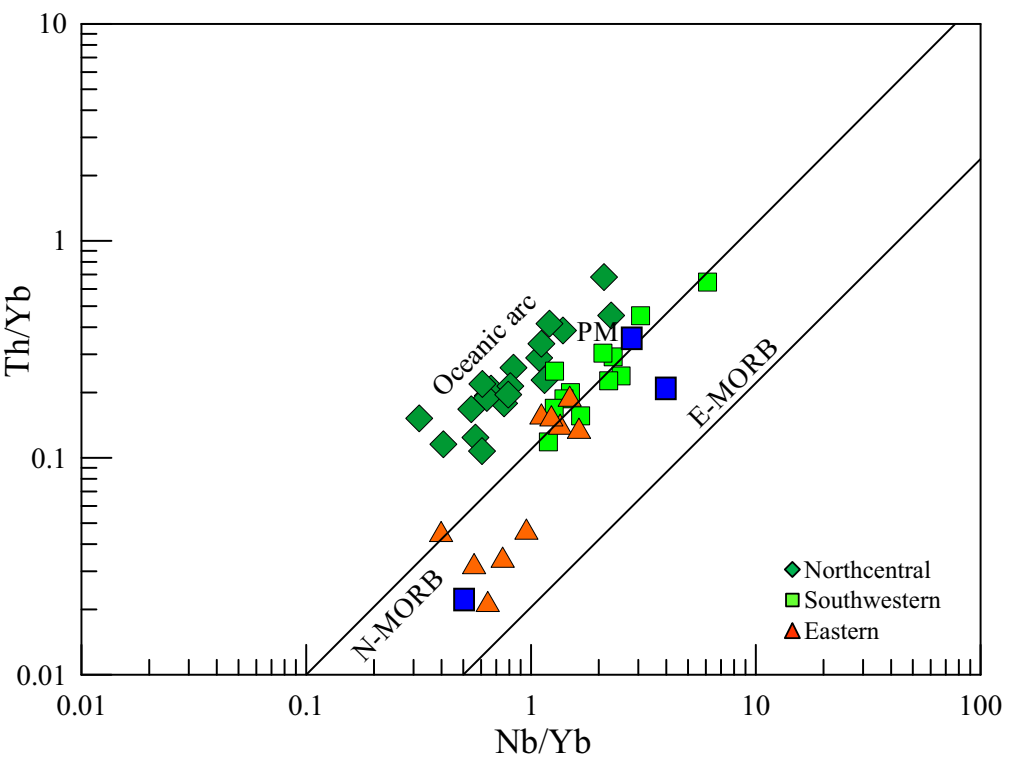

Fig. 6c

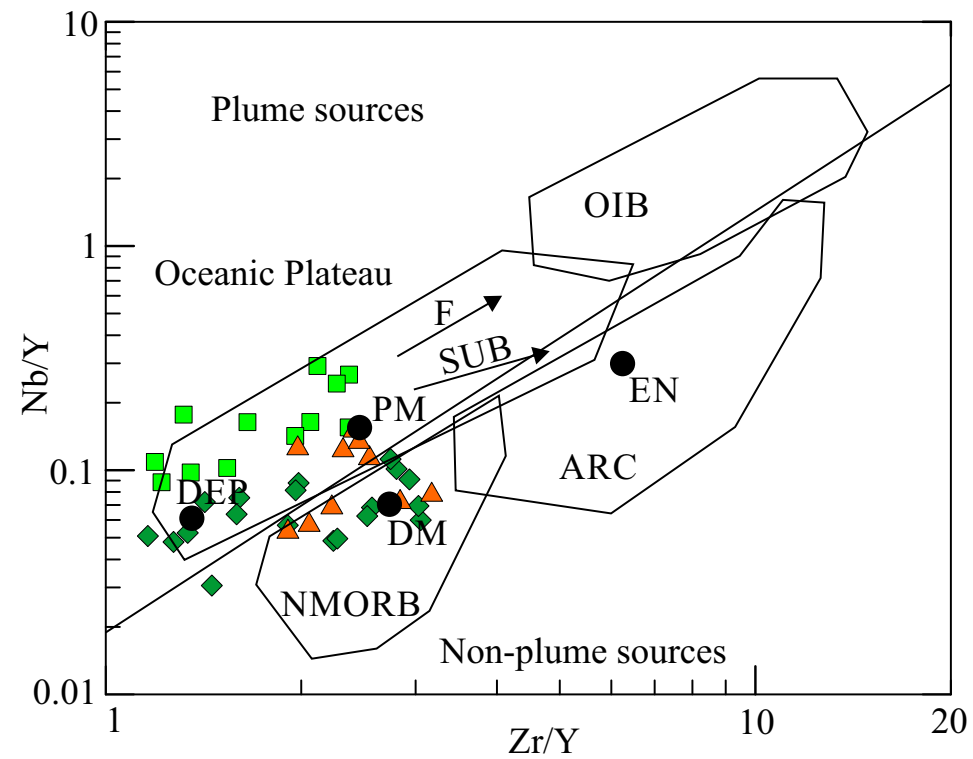

Fig. 7a

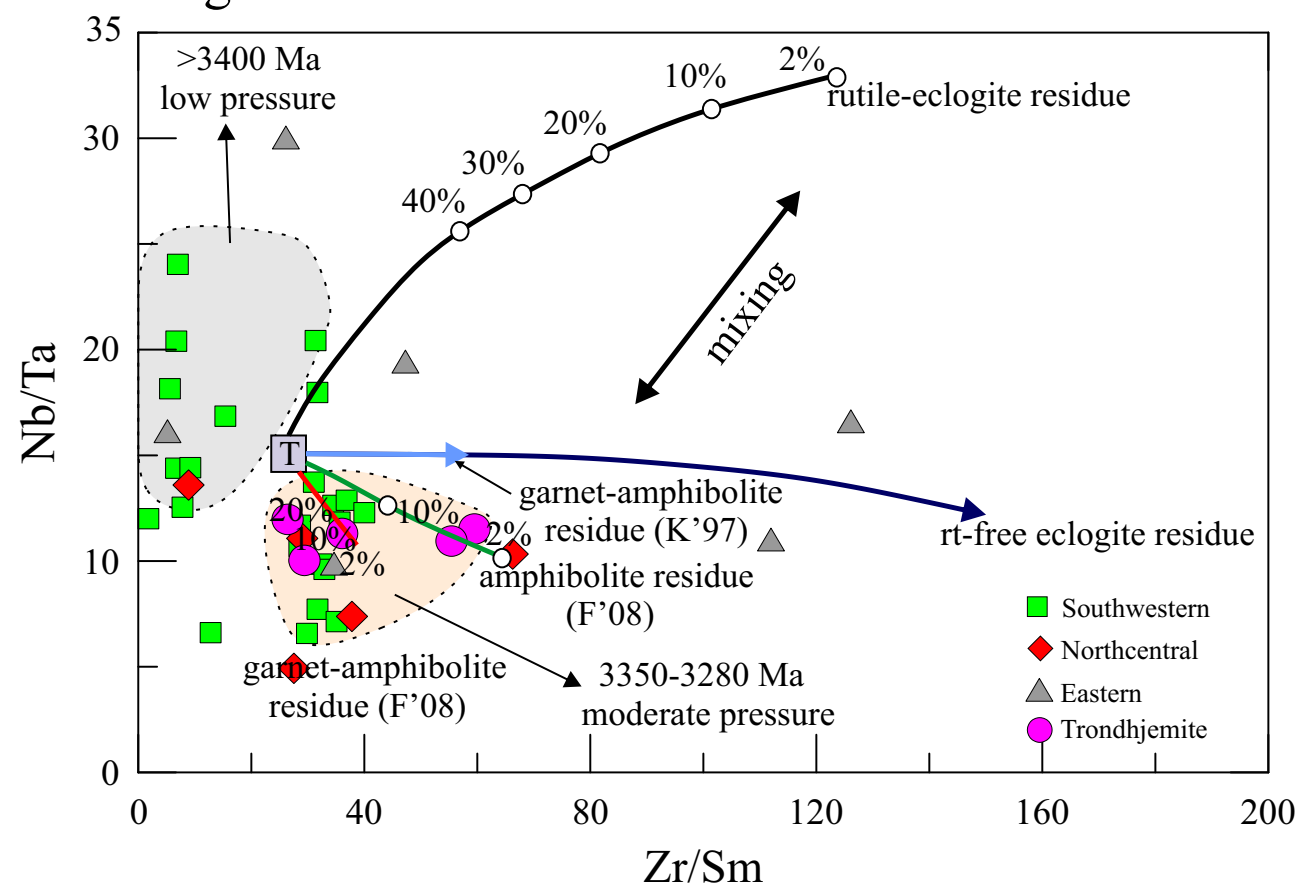


Fig. 7b

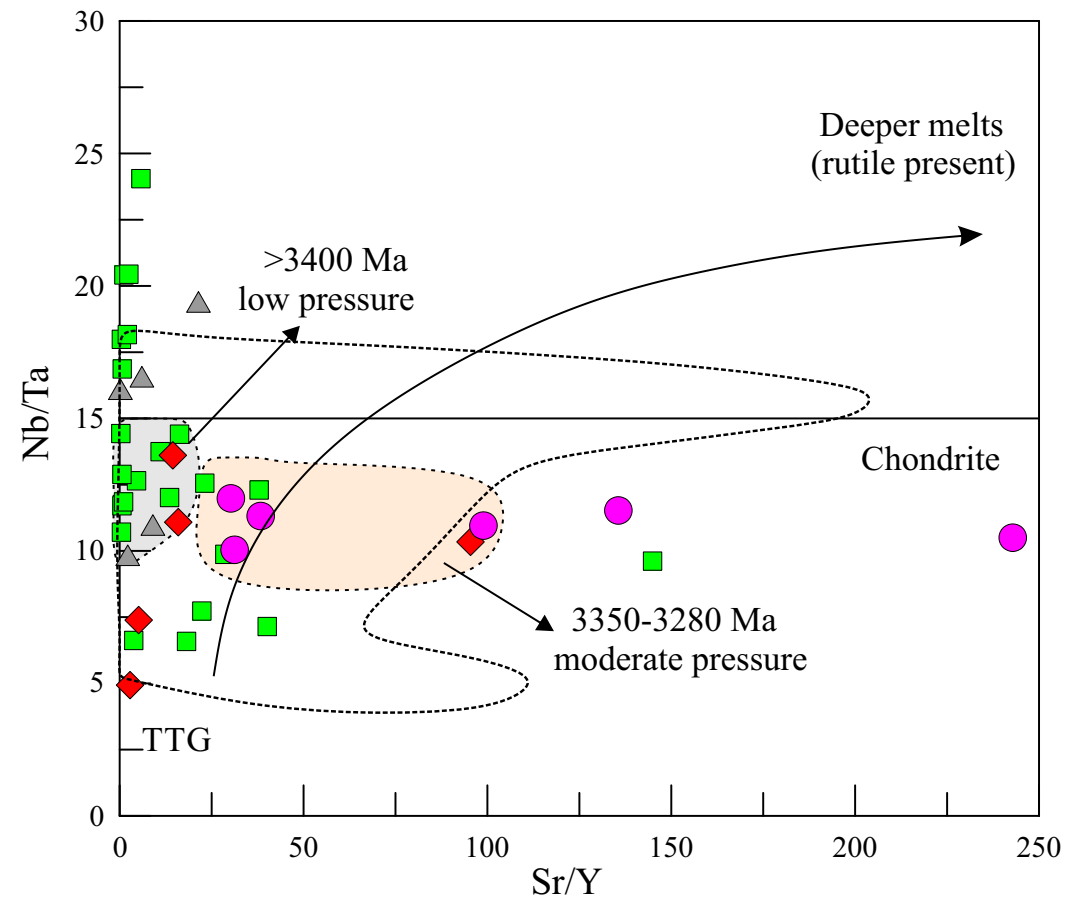

Fig. 7c

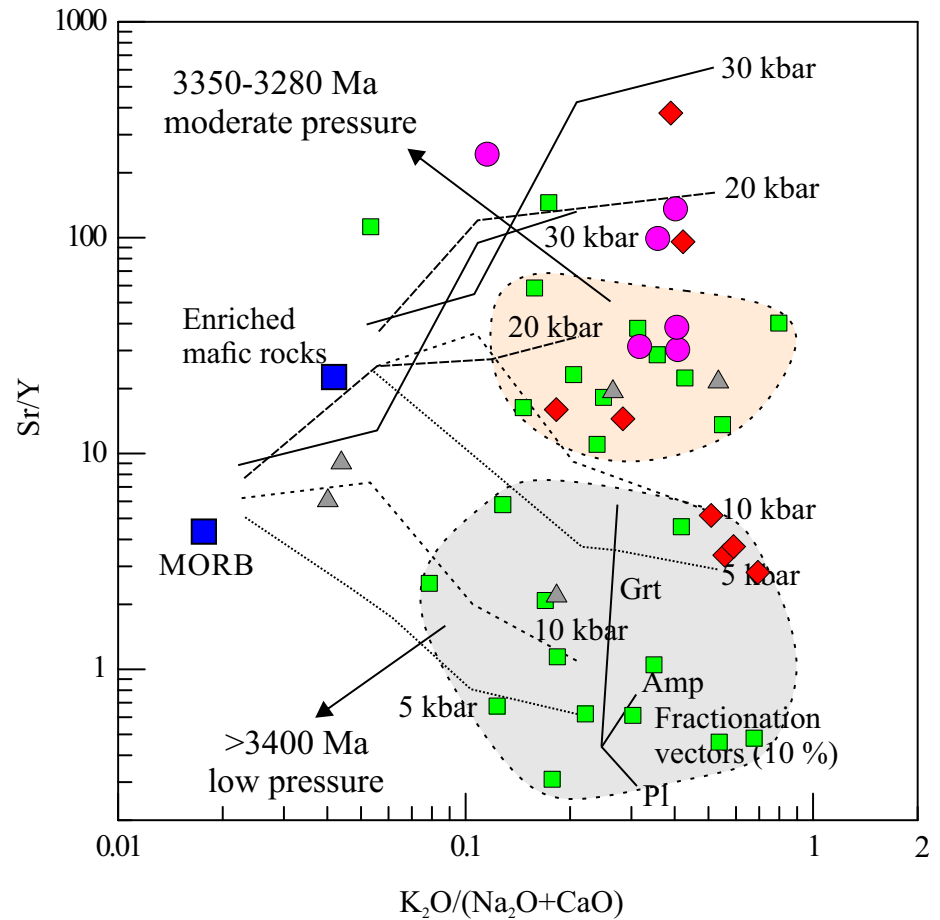

Fig. 8

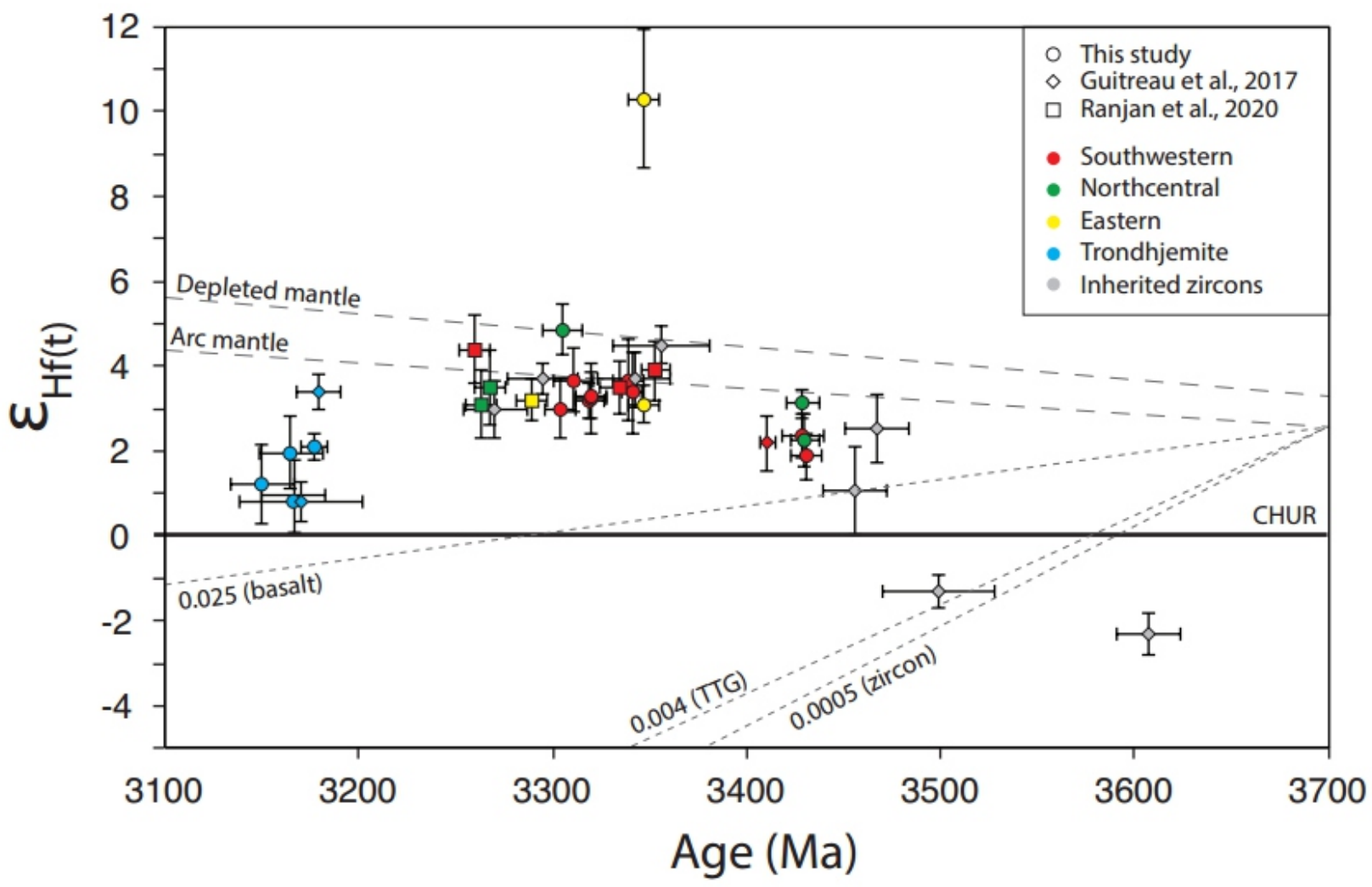


Fig. 9

\section{Ancient microcontinent}
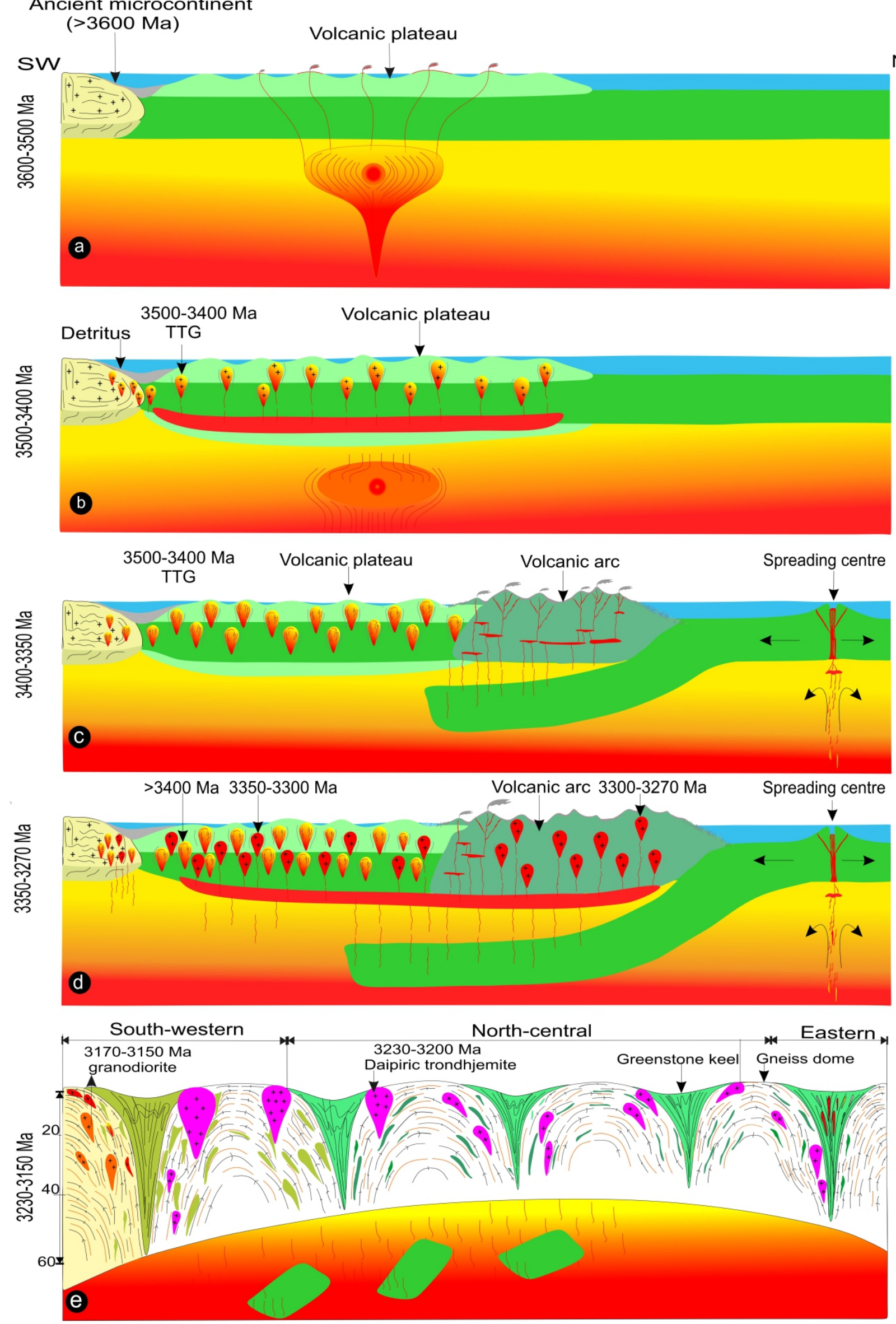
Figures

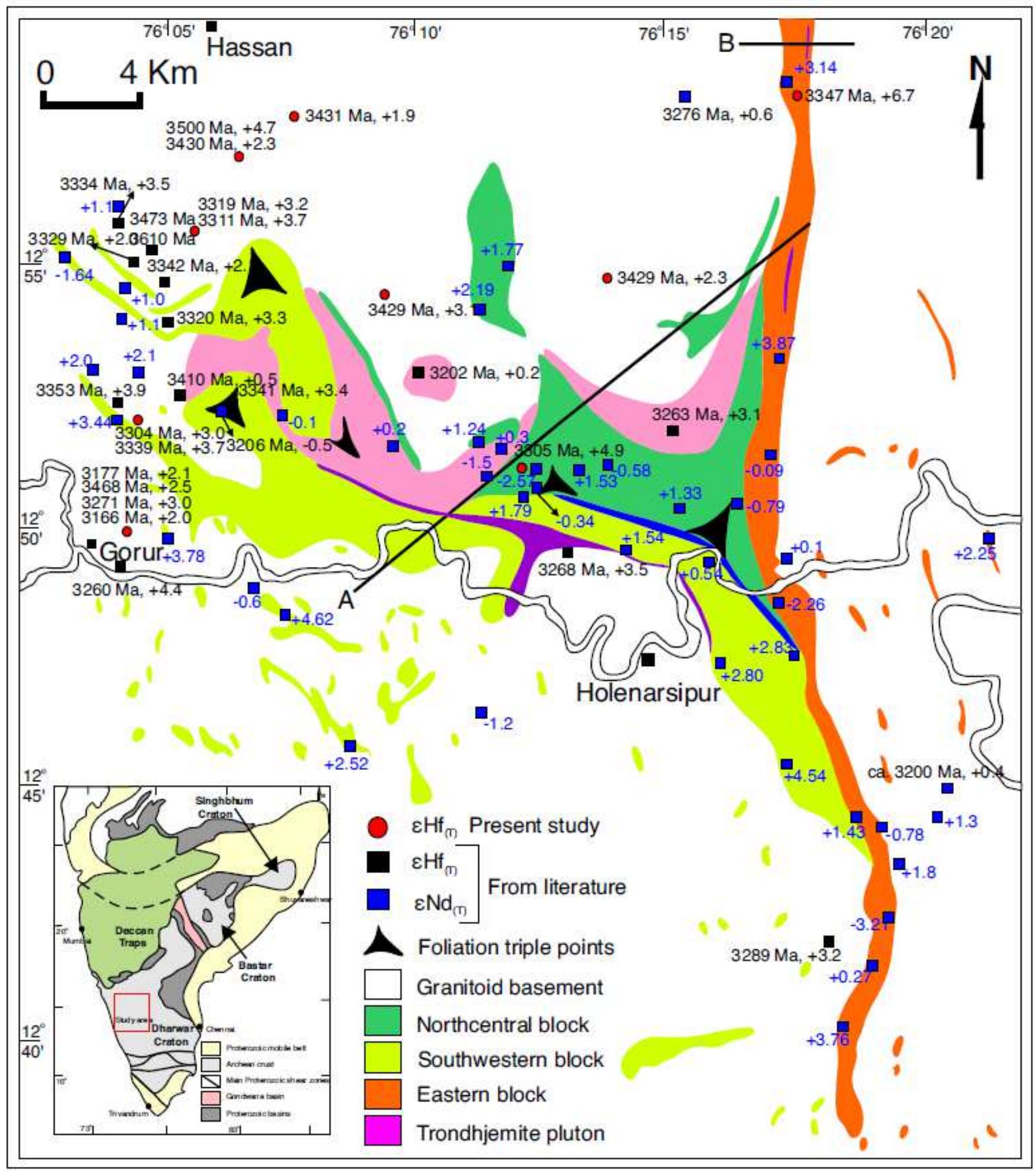

Figure 1

Geological sketch map showing three micro-blocks in the Holenarsipur greenstone belt and adjoining TTGs (with inset map of Peninsular India) showing greenstone units, basement granitoids and diapiric trondhjemite intrusions with age, $\varepsilon \mathrm{Hf}, \varepsilon \mathrm{Nd}$ of the present study; 31-32,43. 


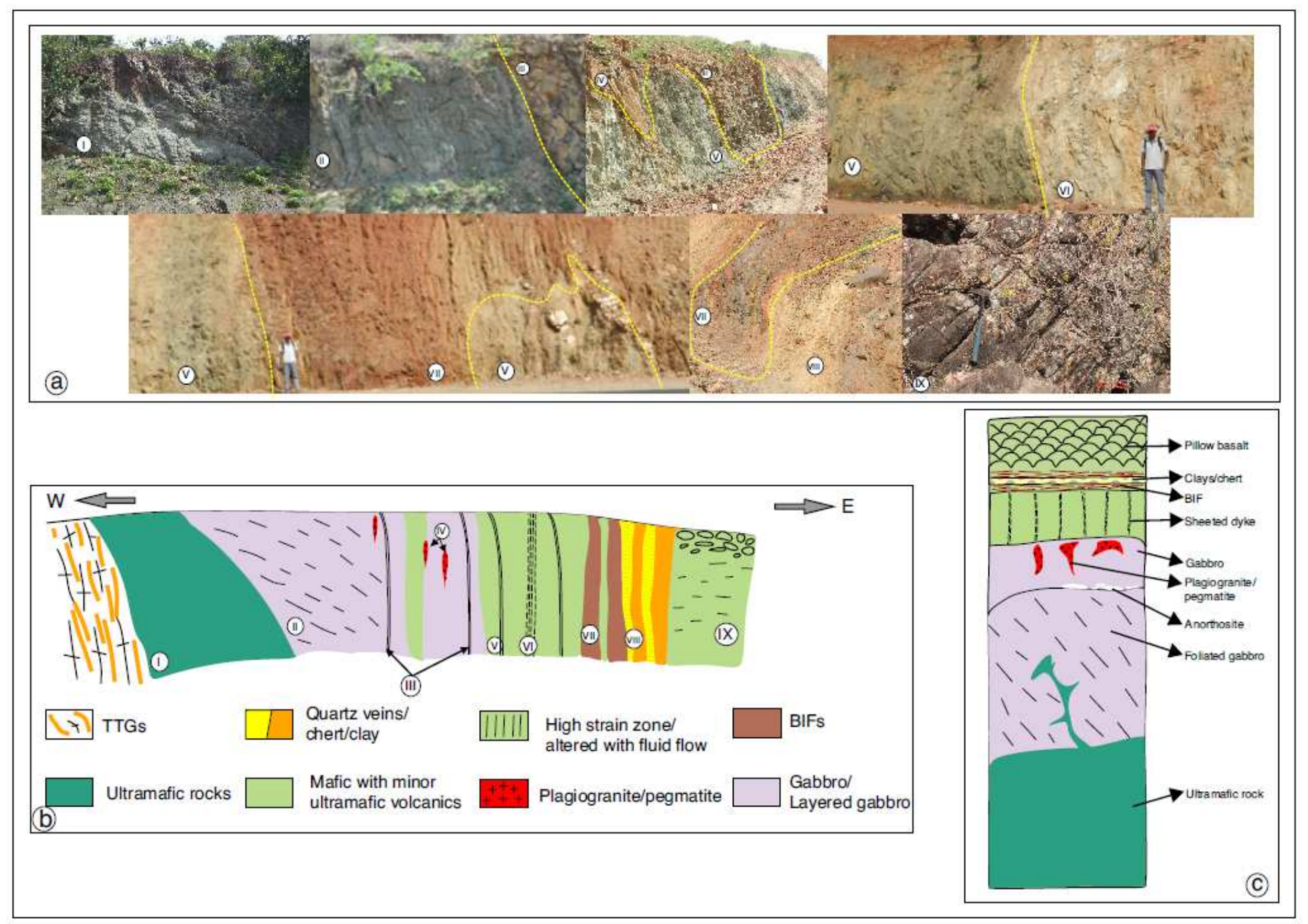

\section{Figure 2}

(a) Eastern block road cut section displaying section of preserved oceanic crust from pillow ultramafic through clays, BIFs, sheeted dykes, plagiogranite, gabbro/norite, layered gabbro with ultramafic and finally peridotite; (b) Interpretative E-W section of preserved oceanic crust. (c) Interpretative vertical section of the oceanic crust

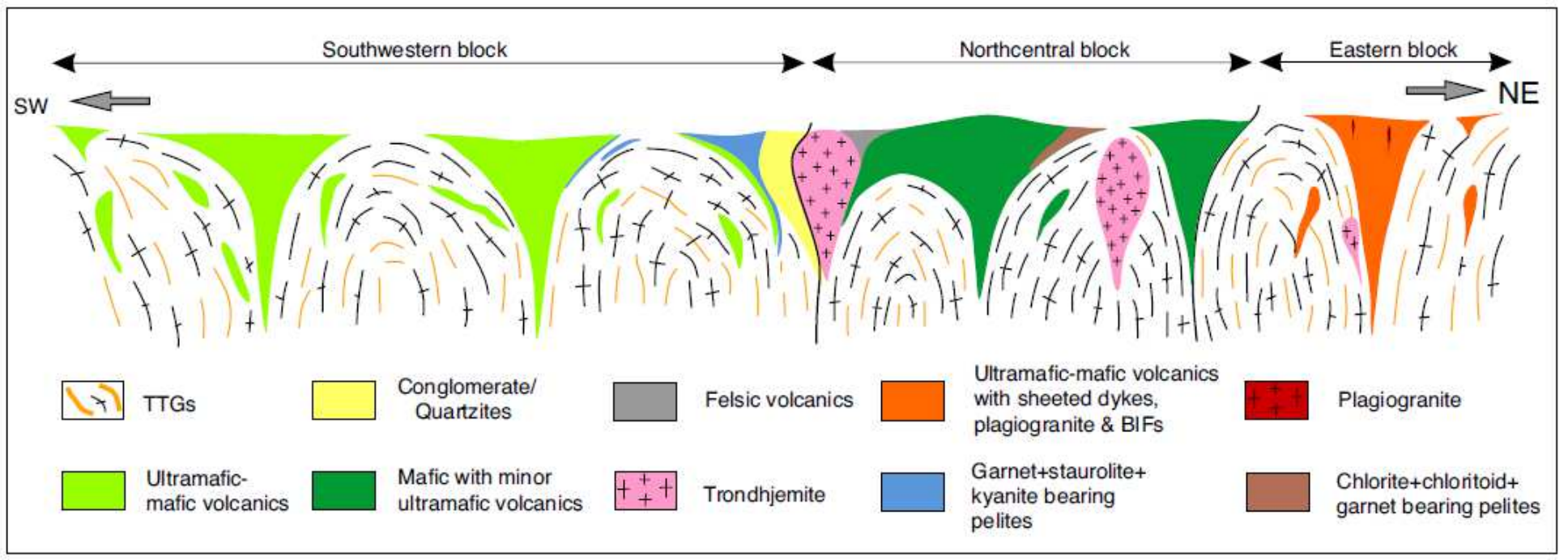


Figure 3

SW-NE interpretative cross section of crustal panel of Holenarsipur greenstone belt and adjoining basement rocks with distinct lithological assemblages corresponding to three micro-blocks.

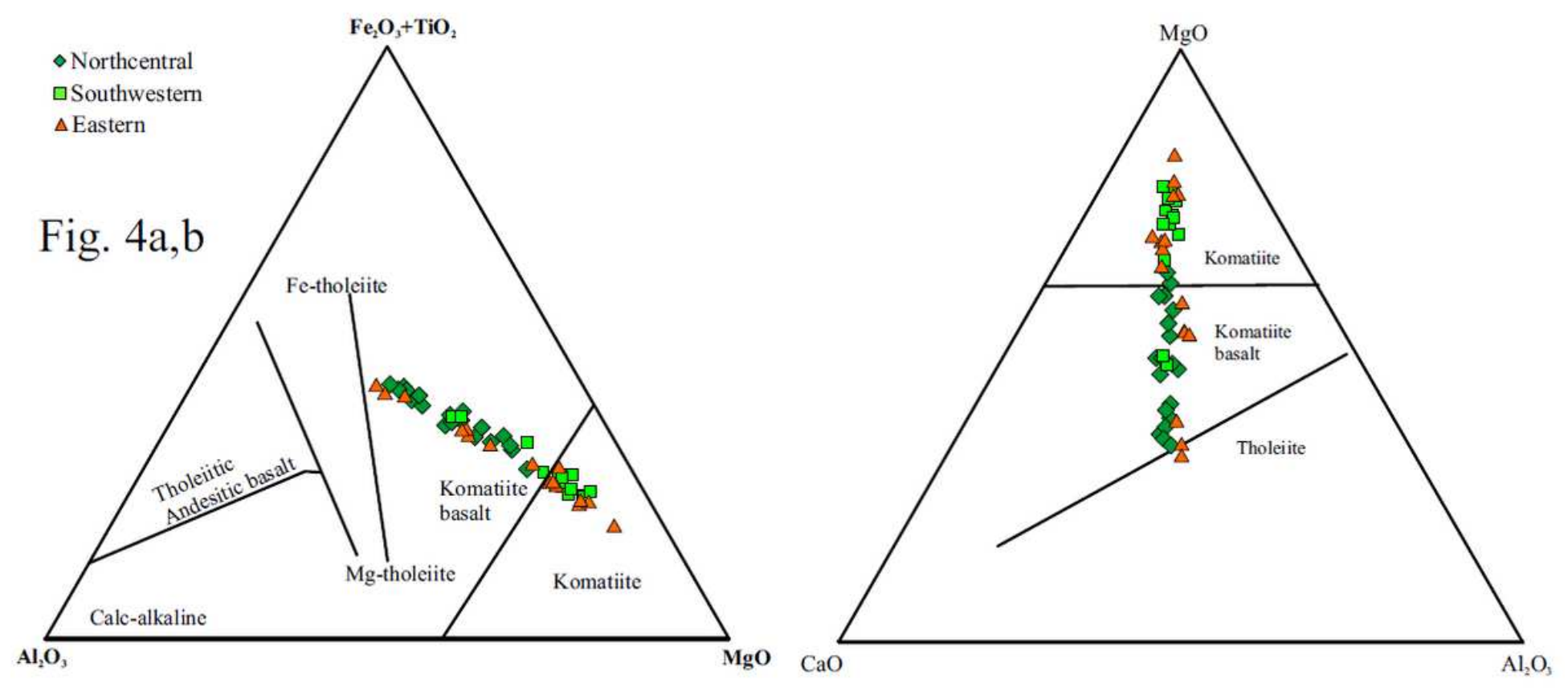

Figure 4

(a) Al2O3-Fe2O3+TiO2- MgO ternary plot73 showing that volcanics of three greenstone unit are komatiite to komatiite basalt composition (b) CaO-MgO-Al2O3 ternary plot74 showing dominant komatiite to komatiite basalt except two samples of Eastern block showing tholeiite composition. 


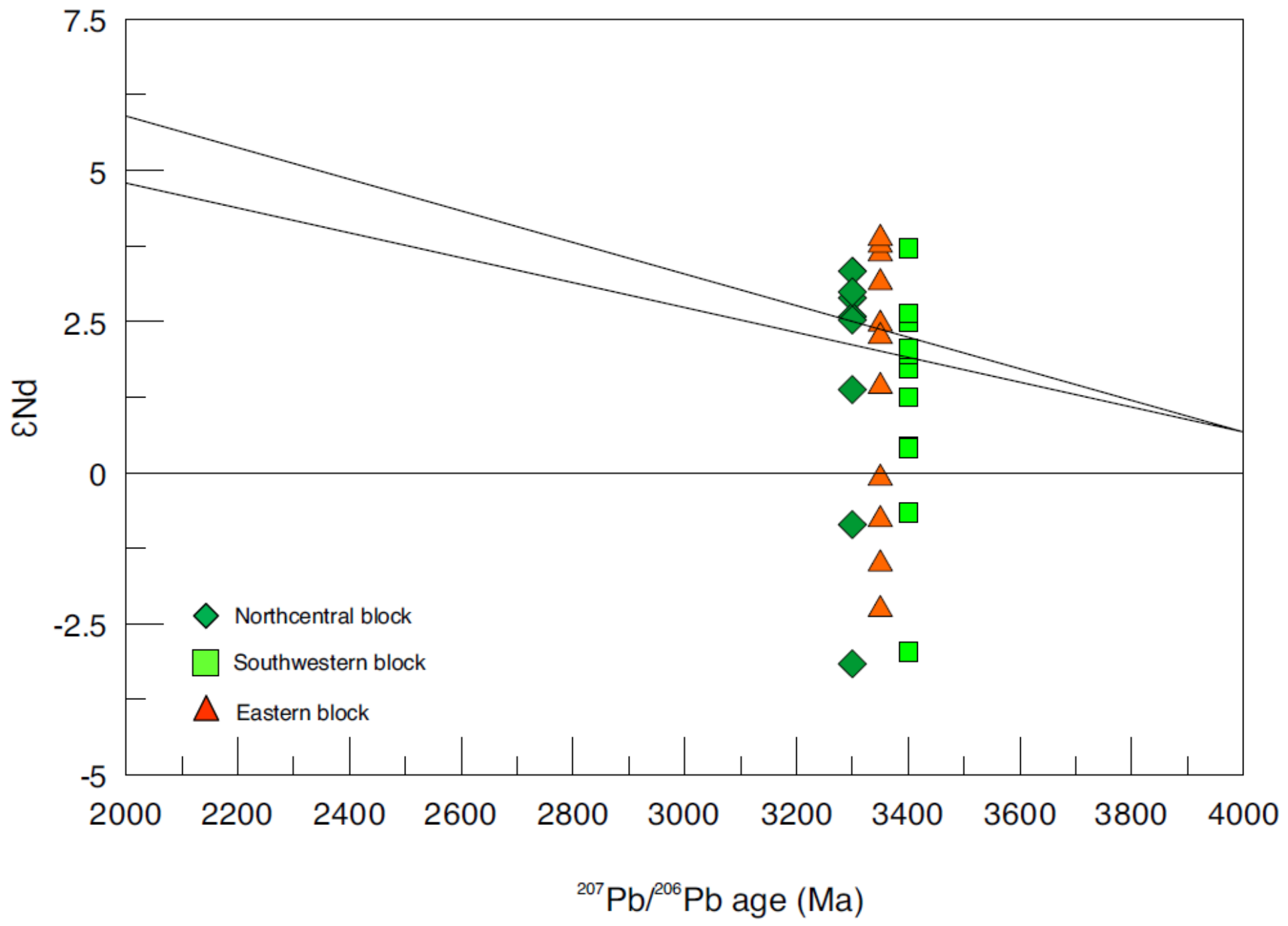

Figure 5

$\llbracket \mathrm{Nd}(\mathrm{T})$ versus time evolution diagram of greenstone volcanics from three blocks showing involvement of depleted mantle with minor ancient crustal contamination. 
Fig. 6a

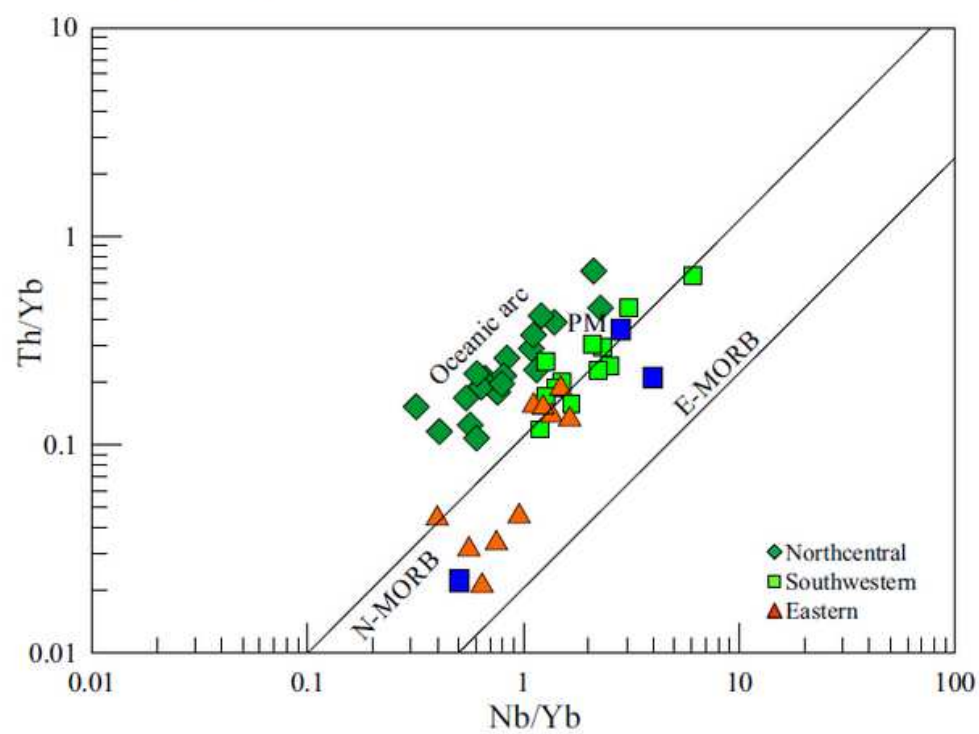

Fig. 6c

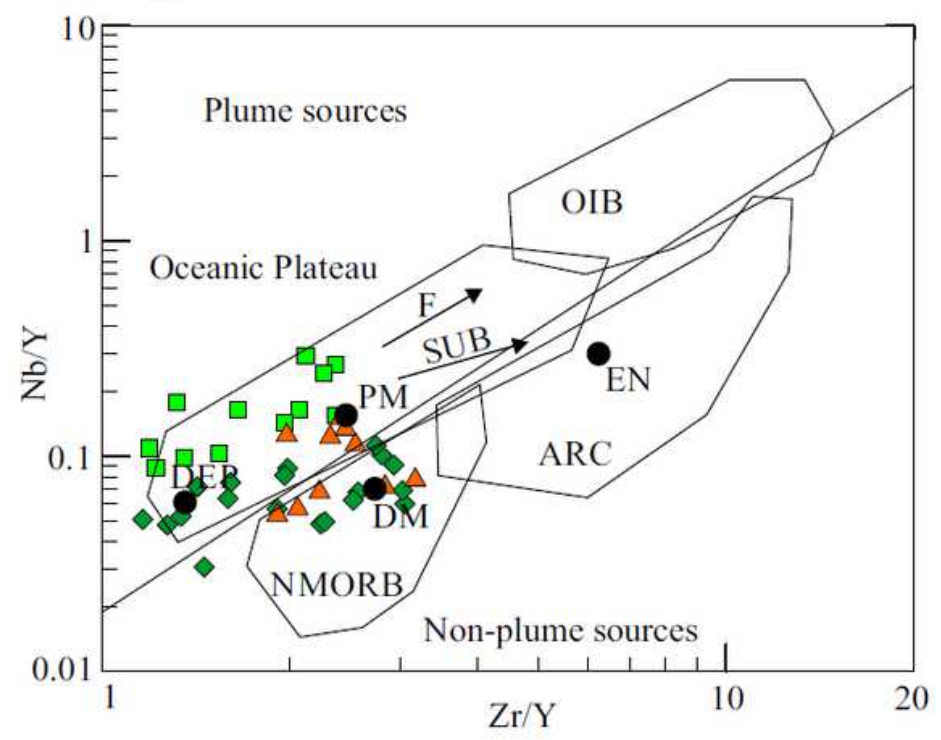

Fig. $6 \mathrm{~b}$

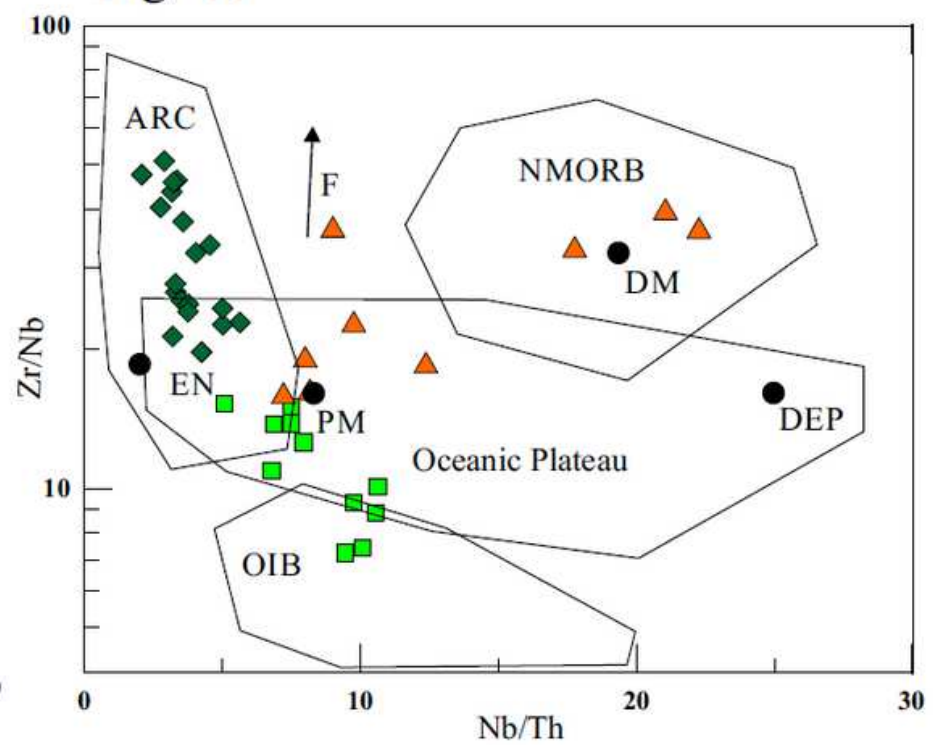

\section{Figure 6}

(a) $\mathrm{Th} / \mathrm{Yb}$ versus $\mathrm{Nb} / \mathrm{Yb}$ binary plot 18 indicating primitive to depleted mantle source for the southwestern, northcentral and eastern block (b) Nb/Y versus Zr/Y77 indicating deep depleted to primitive mantle reservoir source for the samples from southwestern, northcentral and eastern block greenstone volcanics. (c) Zr/Nb versus $\mathrm{Nb} / \mathrm{Th}$ plot77 indicating oceanic plateau for SW block, arc to oceanic plateau for North central block and N-MORB to oceanic plateau for Eastern block. Arrows indicate effects of batch melting (F) and subduction (SUB); PM, primitive mantle; DM, shallow depleted mantle; $\mathrm{ARC}$, arc related basalts; NMORB, normal ocean ridge basalt; OIB, oceanic island basalt; DEP, deep depleted mantle; EN, enriched component. 


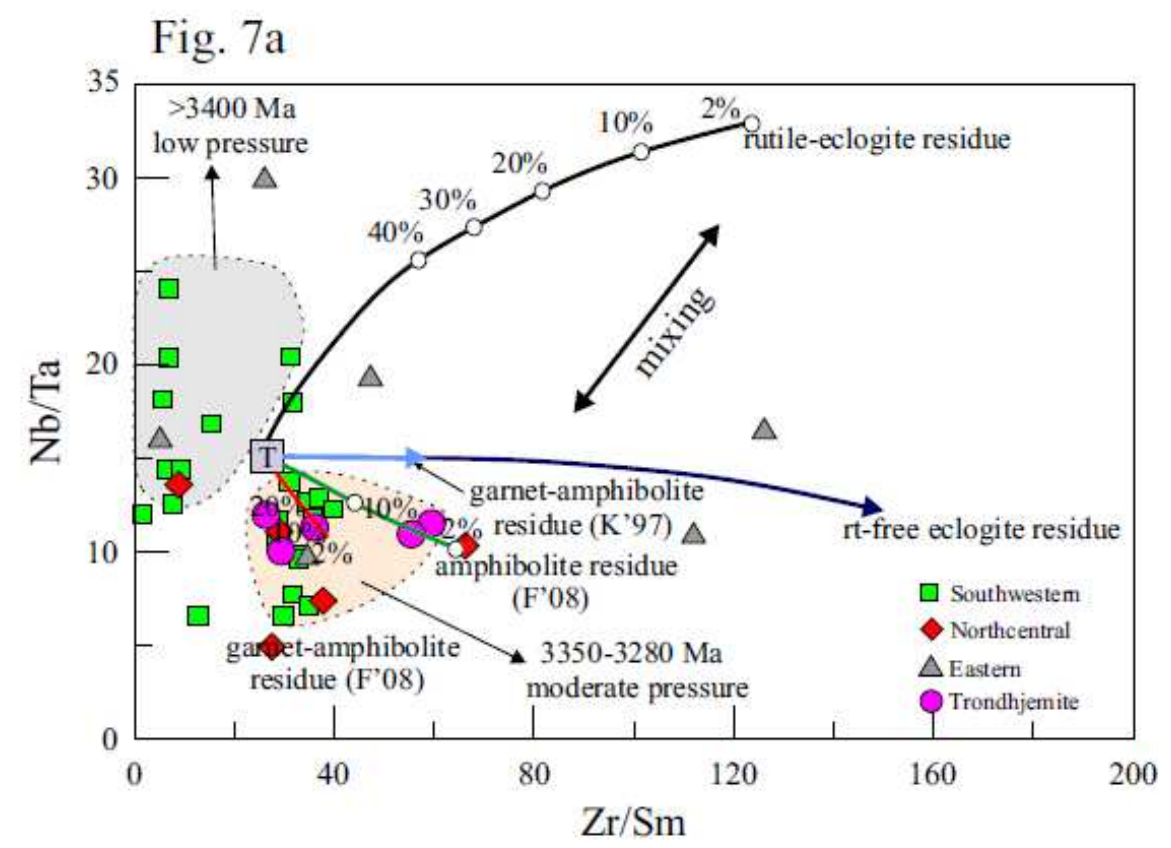

Fig. $7 b$

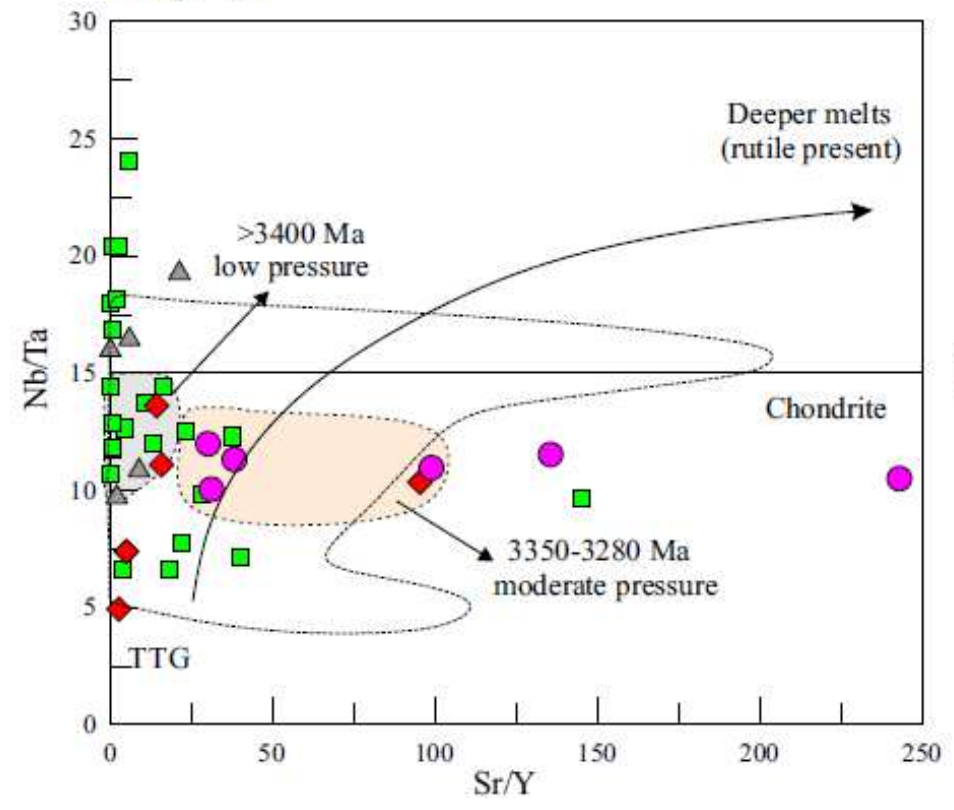

Fig. 7c

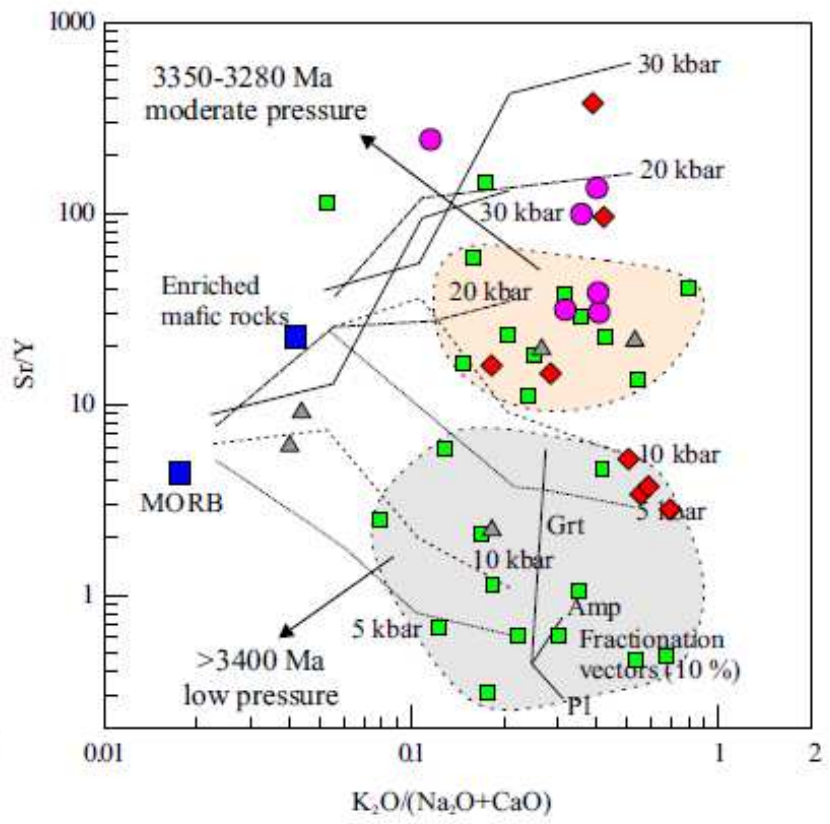

\section{Figure 7}

(a) $\mathrm{Nb} / \mathrm{Ta}$ vs $\mathrm{Zr} / \mathrm{Sm}$ plot 47 explaining the origin of TTG melt from different source composition, (b) $\mathrm{Nb} / \mathrm{Ta}$ vs $\mathrm{Sr} / \mathrm{Y}$ plot78; (c) $\mathrm{K} 2 \mathrm{O} /(\mathrm{Na} 2 \mathrm{O}+\mathrm{CaO})$ vs $\mathrm{Sr} / \mathrm{Y}$ plot79 representing the different pressure level at which the studied samples generated from the mantle. Lines correspond to melting models derived from experimental database, as in 51,78, at different pressures and for two sources, an MORB and a more enriched mafic rock. 


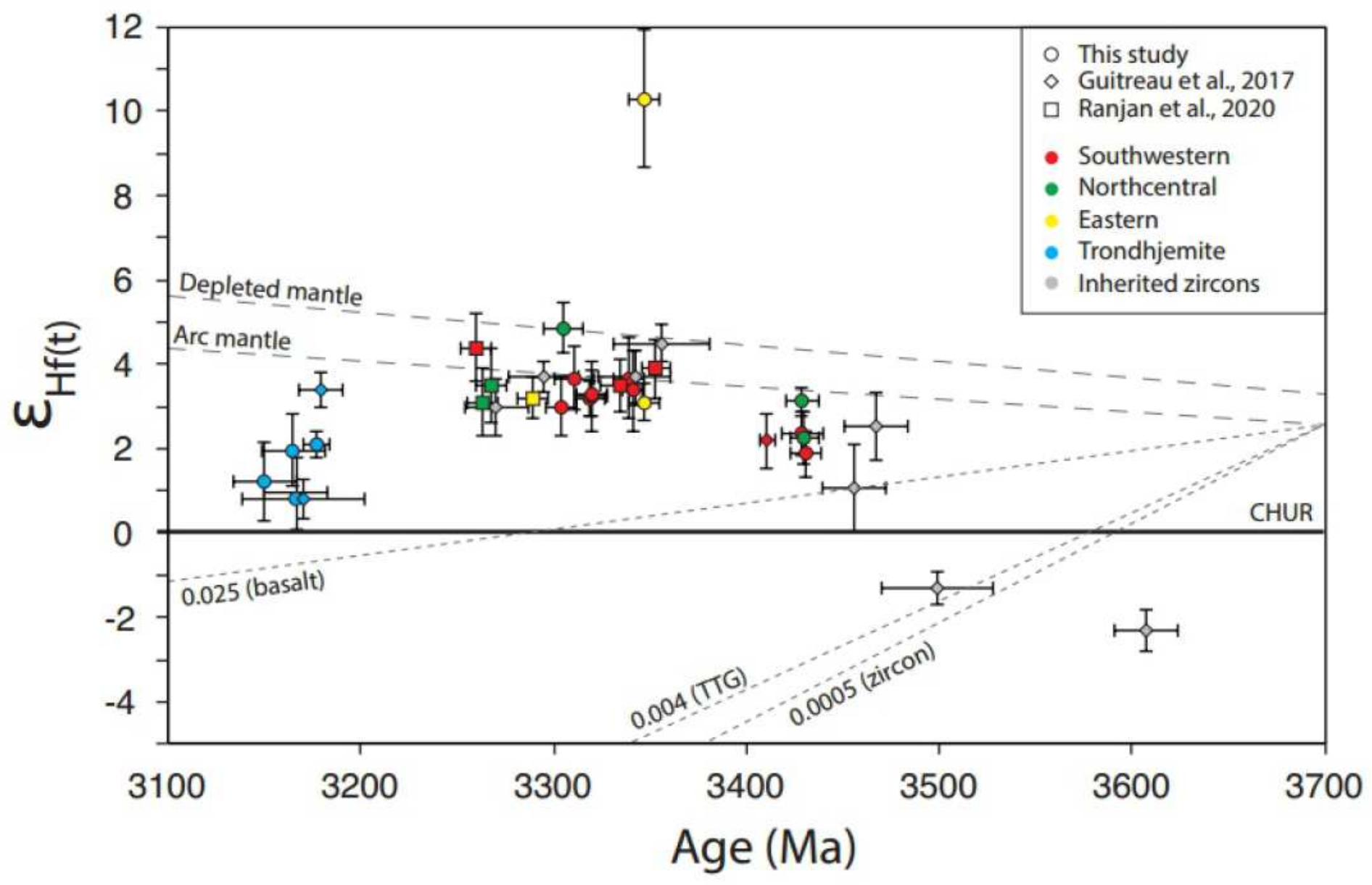

Figure 8

\Hf versus age diagram for zircons from granitoids exposed within Southwestern, Northcentral and Eastern blocks around the Holenarsipur Belt (Western Dharwar craton). Also shown are the evolution of the depleted mantle, assuming a present day $\otimes \mathrm{Hf}$ of +17 , of an arc mantle (present day $\nabla \mathrm{Hf}$ of +13 ), of a typical basalt, TTG and zircon formed from an arc mantle at $3700 \mathrm{Ma}$. Values indicated next to the evolution lines of basalt, TTG and zircon correspond to average 176Lu/177Hf. CHUR refers to Chondritic Uniform Reservoir. 

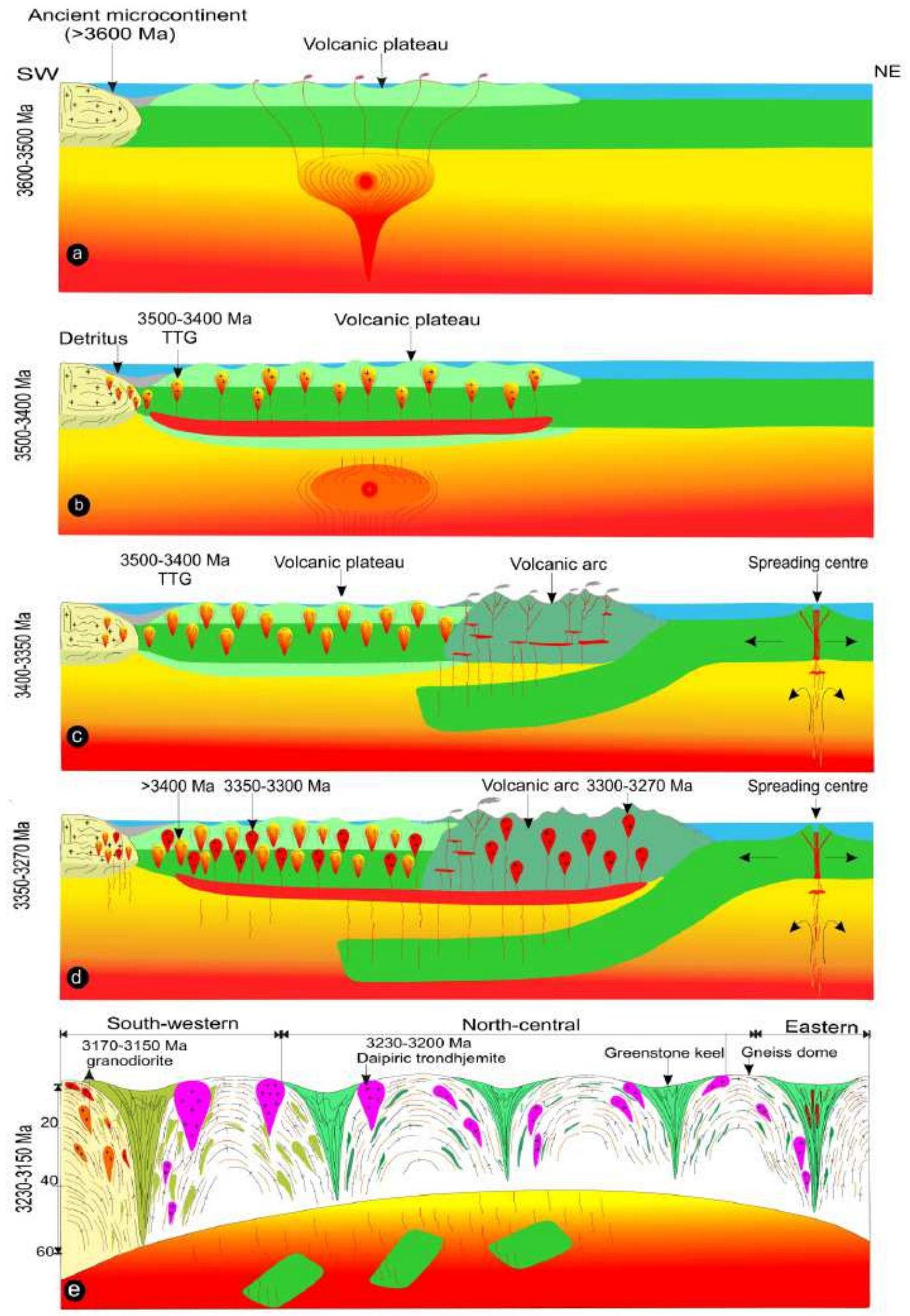

\section{Figure 9}

Proposed tectonic model for origin of Paleoarchean cratons: (a) Formation of plume fed volcanic plateau on stagnant lid ca. $>3500 \mathrm{Ma}$ close to remnant of micro-continent; (b) Continued plume impact caused low pressure melting of stagnant lid to produce magmatic precursors of 3500-3400 Ma TTGs; (c) Initiation of oceanic spreading centre in the east during 3400-3350 Ma caused horizontal motion of stagnant lid with eventual subduction beneath volcanic plateau resulted in the development oceanic 
island arc system; (d) Continued subduction with accumulation hot magmas (generated at greater depth) at the base of arc crust cause melting of arc crust at different depth producing TTG magmas during ca. 3350-3270 Ma; (e) Continued subduction with assembly of oceanic crust, island arc and volcanic plateau and eventual slab breakoff lead to the asthenosphere upwelling caused melting of lower crust/upper most mantle generated hot trondhjemite magmas during ca.3200 Ma; emplacement hot trondhjemite magmas into crust caused partial convective overturn soften crust leading formation of dome and keel structure followed by metamorphism and cratonization ca. 3200-3150 Ma.

\section{Supplementary Files}

This is a list of supplementary files associated with this preprint. Click to download.

- Jayanandaetal2020Naturecommunicationssupplementarymanuscript.pdf 